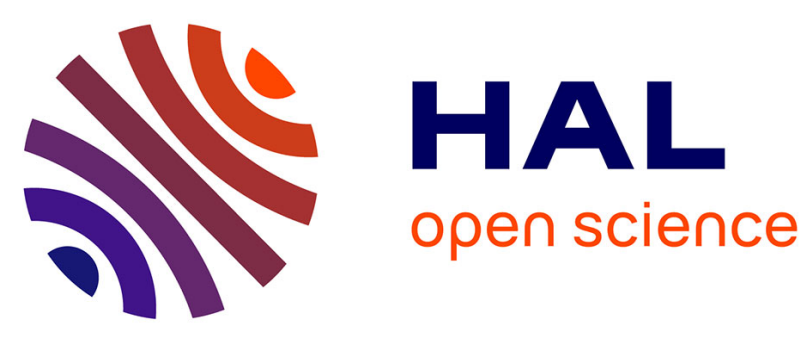

\title{
Reactivity of dinuclear copper(II) complexes towards melanoma cells: Correlation with its stability, tyrosinase mimicking and nuclease activity
}

Cléia Justino Nunes, Beatriz Essenfelder Essenfelder Borges, Lia Sumie Nakao, Eugénie M Peyroux, Renaud M Hardré, Bruno Faure, Marius Réglier, Michel M Giorgi, Marcela M Prieto, Carla Columbano Oliveira, et al.

\section{To cite this version:}

Cléia Justino Nunes, Beatriz Essenfelder Essenfelder Borges, Lia Sumie Nakao, Eugénie M Peyroux, Renaud M Hardré, et al.. Reactivity of dinuclear copper(II) complexes towards melanoma cells: Correlation with its stability, tyrosinase mimicking and nuclease activity. Journal of Inorganic Biochemistry, 2015, 149, pp.49 - 58. 10.1016/j.jinorgbio.2015.05.007 . hal-01475558

\author{
HAL Id: hal-01475558 \\ https://hal.science/hal-01475558
}

Submitted on 23 Feb 2017

HAL is a multi-disciplinary open access archive for the deposit and dissemination of scientific research documents, whether they are published or not. The documents may come from teaching and research institutions in France or abroad, or from public or private research centers.
L'archive ouverte pluridisciplinaire HAL, est destinée au dépôt et à la diffusion de documents scientifiques de niveau recherche, publiés ou non, émanant des établissements d'enseignement et de recherche français ou étrangers, des laboratoires publics ou privés. 


\title{
Reactivity of dinuclear copper(II) complexes towards melanoma cells: Correlation with its stability, tyrosinase mimicking and nuclease activity
}

\author{
Cléia Justino Nunes ${ }^{\mathrm{a}}$, Beatriz Essenfelder Borges ${ }^{\mathrm{b}}$, Lia Sumie Nakao ${ }^{\mathrm{b}}$, Eugénie Peyroux ${ }^{\mathrm{c}}$, Renaud Hardré ${ }^{\mathrm{c}}$, \\ Bruno Faure ${ }^{c}$, Marius Réglier ${ }^{c}$, Michel Giorgi ${ }^{d}$, Marcela Bach Prieto ${ }^{\mathrm{e}}$, \\ Carla Columbano Oliveira ${ }^{\mathrm{e}}$, Ana M. Da Costa Ferreira ${ }^{\mathrm{a}, *}$ \\ a Departamento de Química, Instituto de Química, Universidade de São Paulo, 05508-000 São Paulo, SP, Brazil \\ b Departamento de Patologia Básica, Universidade Federal do Paraná, 81531-990 Curitiba, PR, Brazil \\ c Aix Marseille Université, Centrale Marseille, CNRS, ISM2 UMR 7313, 13397 Marseille, France \\ d Aix Marseille Université, CNRS, Spectropole FR1739, 13397 Marseille, France \\ e Departamento de Bioquímica, Instituto de Química, Universidade de São Paulo, 05508-000 São Paulo, SP, Brazil
}

\section{A R T I C L E I N F O}

Article history:

Received 19 November 2014

Received in revised form 8 May 2015

Accepted 11 May 2015

Available online 19 May 2015

\section{Keywords:}

Dinuclear copper complexes

Tyrosinase mimics

EPR and CD spectroscopies

Cell viability

Melanomas

\begin{abstract}
A B S T R A C T
In this work, the influence of two new dinuclear copper(II) complexes in the viability of melanoma cells (B16F10 and TM1MNG3) was investigated, with the aim of verifying possible correlations between their cytotoxicity and their structure. One of the complexes had a polydentate dinucleating amine-imine ligand (complex $\mathbf{2}$ ), and the other a tridentate imine and a diamine-bridging ligand (complex 4). The analogous mononuclear copper(II) species (complexes $\mathbf{1}$ and $\mathbf{3}$, respectively) were also prepared for comparative studies. Crystal structure determination of complex $\mathbf{2}$ indicated a square-based pyramidal geometry around each copper, coordinated to three $\mathrm{N}$ atoms from the ligand and the remaining sites being occupied by either solvent molecules or counter-ions. Complex 4 has a tetragonal geometry. Interactions of these complexes with human albumin protein (HSA) allowed an estimation of their relative stabilities. Complementary studies of their reactivity towards DNA indicated that all of them are able of causing significant oxidative damage, with single and double strand cleavages, in the presence of hydrogen peroxide. However, nuclease activity of the dinuclear species was very similar and much higher than that of the corresponding mononuclear compounds. Although complex 2 , with a more flexible structure, exhibits a much higher tyrosinase activity than complex $\mathbf{4}$, having a more rigid environment around the metal ion, both complexes showed comparable cytotoxicity towards melanoma cells. Corresponding mononuclear complexes showed to be remarkably less reactive as tyrosinase mimics as well as cytotoxic agents. Moreover, the dinuclear complexes showed higher cytotoxicity towards more melanogenic cells. The obtained results indicated that the structure of these species is decisive for its activity towards the malignant tumor cells tested.
\end{abstract}

(c) 2015 Elsevier Inc. All rights reserved.

\section{Introduction}

Tyrosinase is a ubiquitous enzyme found in bacteria, fungi, animals and humans, capable of catalyzing the oxidation of phenols and catechols to the corresponding quinones [1]. This enzyme plays also a key role in melanogenesis, besides related proteins (TRP-1 and TRP-2), leading to melanins, which are biological polymers produced by melanocytes, and that confer color to the skin, hair, and eyes. Melanins protect the skin from harmful solar radiation, and the level of melanin in epidermis is positively correlated with the tyrosinase activity [2]. The synthesis of melanin initiates by the action of tyrosinases on $L$-3,4-dihydroxyphenylalanine

\footnotetext{
* Corresponding author at: Departamento de Química Fundamental, Instituto de Química, Universidade de São Paulo, Av. Prof. Lineu Prestes, 748, CEP 05508-000, São Paulo, SP, Brazil. Tel.: + 55113091 9147; fax: + 551138155579

E-mail address: amdcferr@iq.usp.br (A.M. Da Costa Ferreira).
}

( $L$-dopa), leading to the formation of both forms of melanins, eumelanin and pheomelanin, possibly involved in the development of malignant melanomas [3]. Melanins can actually have a dual role, acting as a proor as an antioxidant agent. A recent paper on novel properties of melanins reported its capability of coordinating metal ions, such as copper, and binding to DNA, with consequent promotion of DNA strand breaks, probably by a Fenton-type reaction [4]. Further, melanins can also impair the access of repair enzymes to lesions, contributing to the perpetuation of DNA damage. On the other hand, some previous studies presented results on the stimulation of proliferation and differentiation of melanocytes by melanotropin, a melanocyte-stimulating hormone [5]. This effect however could be overcome if the culture medium was frequently changed or the concentration of tyrosinase decreased. The presence of an inhibitor of growth in the culture media of actively melanizing melanoma cells was reported as a function of tyrosinase activity level and tyrosine concentration, when both enzyme and substrate were added exogenously [6]. 
Taking into account that copper ions in the active site of tyrosinase could be responsible for both activities, formation of melanin and, possibly, stimulation of melanoma growth, a study to verify the influence of tyrosinase mimics on the viability of melanoma cells was carried out. The aim was to establish possible correlations between an observed stimulation or inhibition in melanoma cells growth, and the structure of some copper(II) complexes. Two new structurally related dinuclear complexes, one with a polydentate dinucleating amine-imine ligand, and the other with a tridentate imine and a diamine-bridging ligand, were then prepared and investigated (complexes $\mathbf{2}$ and $\mathbf{4}$, shown in Fig. 1). The corresponding mononuclear copper(II) species (complexes 1 and 3, respectively) were also isolated, and used in comparative studies. These complexes showed to be thermodynamically stable through CD measurements, using HSA as copper competitive ligand. Additionally, oxidative damage to DNA caused by these complexes, in the presence of hydrogen peroxide, was verified in complementary studies.

\section{Experimental}

\subsection{Materials}

Most of the reagents (percent purity) used: 2-(acetyl)pyridine (99\%), 2,3-bis(pyridyl)pyrazine, histamine hydrochloride (99\%), isatin (98\%), 2-(2-aminoethyl)pyridine (95\%), copper(II) perchlorate hexahydrated (98\%) and copper(II) triflate (98\%) were purchased from Aldrich Chemical Co. Solvents ethanol (96\%), ethanol absolute (99\%), methanol (99\%), dichloromethane (99\%) and acetone (99\%), as well as hydrochloric acid were from Merck Chemical Co. DNA sodium salt from calf thymus (CT-DNA) and human serum albumin (HSA) were from Sigma-Aldrich. All the solutions were prepared with deionized water from a Millipore instrument.

\subsection{Syntheses of the ligands and corresponding complexes}

\subsubsection{Ligand 2,2'-bis(aminomethyl)diphenyl}

$2,2^{\prime}$-Bis(aminomethyl)biphenyl (dpam) was prepared in 2 steps by a Gabriel's reaction from 2,2'-bis(bromomethyl)biphenyl [7] according to a described procedure [8]. $\mathrm{N}$-benzyl- $\mathrm{N}$-bis(2-pyridylethyl)amine (N22) was prepared by addition of benzylamine to an excess of 2vinylpyridine, according to a procedure reported in the literature [9].

\subsection{2. $\quad N^{2}, N^{2}, N^{2}, N^{2}$-tetrakis[2-(2-pyridyl)ethyl][1-1'-biphenyl]-2,2'- dimethylamine (N22-N22) \\ To a solution of 2,2'-bis(aminomethyl)diphenyl (1.05 g, $5 \mathrm{mmol}$ ) in} anhydrous methanol (30 mL) maintained under argon, freshly distilled 2-vinylpyridine $(6.42 \mathrm{~g}, 61 \mathrm{mmol})$ and glacial acetic acid $(0.35 \mathrm{~g}$, $5.8 \mathrm{mmol}$ ) were carefully added. After a 5-day reflux under argon, the mixture was then extracted in dichloromethane, and washed with $\mathrm{NaOH}(1 \mathrm{M}, \mathrm{pH} \approx 12$ ). Organic layers were dried over sodium sulfate, filtered and evaporated under vacuum. The resulting yellow oil was chromatographied on silica gel with $\mathrm{CH}_{2} \mathrm{Cl}_{2} / \mathrm{MeOH}$ (95/5) and finally with $\mathrm{CH}_{2} \mathrm{Cl}_{2} / \mathrm{MeOH} / \mathrm{NH}_{3}(90 / 10 / 1)$. Ligand N22-N22 was obtained as pale yellow oil (1.3 g, 41\%). MS (FAB +) [MS = mass spectrometry, $\mathrm{FAB}=$ fast atomic bombardment]: $\mathrm{m} / \mathrm{z}=633,3692[\mathrm{M}+1](100)$; $\mathrm{C}_{42} \mathrm{H}_{44} \mathrm{~N}_{6} \mathrm{FW}=632.84 \mathrm{~g} / \mathrm{mol}$. ${ }^{\mathbf{1}} \mathbf{H}$ RMN $\left(300 \mathrm{MHz}, \mathrm{CDCl}_{3}\right)$ in $\delta(\mathrm{ppm})$ : $8.46(\mathrm{dd}, \mathrm{J}=0.8 \mathrm{~Hz}, \mathrm{~J}=4.1 \mathrm{~Hz}, 4 \mathrm{H}) ; 7.50(\mathrm{dt}, \mathrm{J}=1.7 \mathrm{~Hz}, \mathrm{~J}=7.7 \mathrm{~Hz}$, $4 \mathrm{H}) ; 7.32(\mathrm{~m}, 2 \mathrm{H}) ; 7.19(\mathrm{dd}, \mathrm{J}=3.8 \mathrm{~Hz}, \mathrm{~J}=5.2 \mathrm{~Hz}, 4 \mathrm{H}) ; 7.06(\mathrm{dd}, \mathrm{J}=$ $4.9 \mathrm{~Hz}, \mathrm{~J}=7.5 \mathrm{~Hz}, 4 \mathrm{H}) ; 6.99(\mathrm{~m}, 6 \mathrm{H}) ; 3.38(\mathrm{~s}, 4 \mathrm{H}) ; 2,78(\mathrm{~s}, 8 \mathrm{H}) .{ }^{13} \mathrm{C}$ RMN $\left(50 \mathrm{MHz}, \mathrm{CDCl}_{3}\right)$ in $\delta$ (ppm): 160.46 (4C Py, where Py = pyridine); 148.84 (4CH Py); 140.51 (2C Ph); 137.34 (2C Ph); 135.93 (4CH Py); 129.40 (2CH Ph); $128.61(2 \mathrm{CH} \mathrm{Ph}) ; 126.98(2 \mathrm{CH} \mathrm{Ph}) ; 125.96(2 \mathrm{CH}$ $\mathrm{Ph}) ; 123.21$ (4CH Py); 1120.81 (4CH Py); $55.49\left(2 \mathrm{CH}_{2}-\mathrm{Ph}\right) ; 53.59$ $\left(4 \mathrm{CH}_{2}-\mathrm{Py}\right) ; 35.58\left(4 \mathrm{CH}_{2}-\mathrm{N}\right)$.

\subsubsection{Complex $\left[\mathrm{Cu}(\mathrm{N} 22)\left(\mathrm{H}_{2} \mathrm{O}\right)\left(\mathrm{CF}_{3} \mathrm{SO}_{3}\right)\right]\left(\mathrm{CF}_{3} \mathrm{SO}_{3}\right) \mathrm{I}$}

Copper complex $[\mathrm{Cu}(\mathrm{N} 22)]\left(\mathrm{CF}_{3} \mathrm{SO}_{3}\right)_{2} 1$ was prepared in good yields (75\%) by complexation of 1 eq. of copper(II) triflate with 1 eq. of $\mathrm{N}$ benzyl- $N$-bis(2-pyridylethyl)amine in methanol [10]. Calc. for $\mathrm{C}_{2} \mathrm{H}_{23}$ $\mathrm{N} \mathrm{F} \mathrm{S}_{2} \mathrm{O}_{6} \mathrm{Cu}(\mathrm{FW}=679.11 \mathrm{~g} / \mathrm{mol}): \mathrm{C}, 40.68 ; \mathrm{H}, 3.41 ; \mathrm{N}, 6.19 ; \mathrm{Cu}$, 9.36\%; Experim. values: C, 41.09; H, 3.14; N, 6.25; Cu, 9.22\%. UV-vis bands, $\lambda_{\text {max }}, \mathrm{nm}\left(\varepsilon, 10^{3} \mathrm{M}^{-1} \mathrm{~cm}^{-1}\right): 261$ (13.5), $268 \mathrm{~s}$ (10.6), 684 (0.142).

\subsubsection{Complex $\left[\mathrm{Cu}_{2}(\mathrm{~N} 22-22)\left(\mathrm{H}_{2} \mathrm{O}\right)_{2}\left(\mathrm{CF}_{3} \mathrm{SO}_{3}\right)_{2}\right]\left(\mathrm{CF}_{3} \mathrm{SO}_{3}\right)_{2} 2$}

This complex was prepared according to a procedure previously developed [11,12]. To a methanolic solution (10 ml) of copper(II) triflate (558 mg, $1.54 \mathrm{mmol}), 487 \mathrm{mg}(0.77 \mathrm{mmol})$ of the ligand N22-22 dissolved in $10 \mathrm{ml}$ methanol was added, under stirring. The blue solution obtained was maintained under stirring for $2 \mathrm{~h}$, and after the addition of some diethyl ether a precipitate was formed. The suspension was filtrated, the precipitate washed with $50 \mathrm{~mL}$ ether, and after dried gave $622 \mathrm{mg}$ of a blue powder (64\% yield). After a slow evaporation of a methanolic solution of this compound, blue crystals suitable for crystallographic analysis were isolated. Calc. for $\mathrm{C}_{44} \mathrm{H}_{44} \mathrm{Cu}_{2} \mathrm{~F}_{6} \mathrm{~N}_{6} \mathrm{O}_{6} \mathrm{~S}_{2}$ $(\mathrm{FW}=1392.22 \mathrm{~g} / \mathrm{mol}): \mathrm{C}, 40.68 ; \mathrm{H}, 3.41 ; \mathrm{N}, 6.19 ; \mathrm{Cu}, 9.36 \%$; Experim. values: C, 41.25; H, 3.18; N, 6.23; Cu, 8.96\%. ESI-MS m/z = 528.1, calculated for $\mathrm{C}_{44} \mathrm{H}_{44} \mathrm{Cu}_{2} \mathrm{~F}_{6} \mathrm{~N}_{6} \mathrm{O}_{6} \mathrm{~S}_{2}=528.07$. UV-vis bands, $\lambda_{\text {max }}, \mathrm{nm}(\varepsilon$, $10^{3} \mathrm{M}^{-1} \mathrm{~cm}^{-1}$ ): 261 (45.7), $268 \mathrm{~s}$ (37.2), 684 (0.275).

\subsubsection{Crystal structure determination and refinement}

Crystal data for the complex $\left[\mathrm{Cu}_{2}(\mathrm{~N} 22-22)\left(\mathrm{H}_{2} \mathrm{O}\right)_{2}\left(\mathrm{CF}_{3} \mathrm{SO}_{3}\right)_{2}\right]$ $\left(\mathrm{CF}_{3} \mathrm{SO}_{3}\right)_{2} 2$ together with the details of X-ray diffraction experiments are reported in Tables 1 to 3. Measurements were made on a BrukerNonius KappaCCD diffractometer with graphite monochromatized $\operatorname{Mo}(K \alpha)$ radiation $(\lambda=0.71073 \AA)$. The structures were solved by direct methods and refinements, based on $\mathrm{F}^{2}$, made by full-matrix leastsquares techniques. The $\mathrm{H}$ atoms for the water molecule were placed at idealized positions in order to optimize the H-bonds with the oxygen atoms of the closest triflate counter-ions. The CIF file with data for complex $\mathbf{2}$ has been deposited at the Cambridge Crystallographic Data Centre, CCDC 1030475.

\subsubsection{Complex [Cu(apyhist) $\left.\mathrm{H}_{2} \mathrm{O}\right]\left(\mathrm{ClO}_{4}\right)_{2} 3$}

The imine ligand apyhist, where apyhist = ligand obtained from 2-(acetyl)pyridine and histamine (see Fig. 1), was prepared according to methods already described in previous works $[13,14]$, through condensation reaction of suitable carbonyl and amine precursors, followed by immediate in situ metallation. The formed imine copper(II) complex

Table 1

Crystallographic data for complex $\left[\mathrm{Cu}_{2}(\mathrm{~N} 22-22)\left(\mathrm{H}_{2} \mathrm{O}\right)_{2}\left(\mathrm{CF}_{3} \mathrm{SO}_{3}\right)_{2}\right]\left(\mathrm{CF}_{3} \mathrm{SO}_{3}\right)_{2} 2$.

\begin{tabular}{ll}
\hline$\left[\mathrm{Cu}_{2}{ }_{2}(\mathrm{~N} 22-22)\left(\mathrm{CF}_{3} \mathrm{SO}_{3}\right)_{4 / 3}\left(\mathrm{H}_{2} \mathrm{O}\right)_{8 / 3}\right]$ & \\
\hline Formula & $\mathrm{C}_{147} \mathrm{H}_{172} \mathrm{Cu}_{6} \mathrm{~F}_{36} \mathrm{~N}_{18} \mathrm{O}_{50} \mathrm{~S}_{12}$ \\
Molecular weight & 4440.99 \\
Crystal system & Triclinic \\
Space group & $\mathrm{P}-1$ \\
$\mathrm{Z}$ & 2 \\
$\mathrm{a}(\AA)$ & $19.7799(4)$ \\
$\mathrm{b}(\AA)$ & $22.6303(8)$ \\
$\mathrm{c}(\AA)$ & $23.049(1)$ \\
$\alpha\left({ }^{\circ}\right)$ & $70.399(4)$ \\
$\beta\left({ }^{\circ}\right)$ & $78.025(2)$ \\
$\gamma\left({ }^{\circ}\right)$ & $73.780(1)$ \\
$\mathrm{V}\left(\AA^{3}\right)$ & $9258.4(6)$ \\
$\rho\left(\mathrm{g} \cdot \mathrm{cm}^{-3}\right)$ & 1.593 \\
$\mathrm{~N}^{\circ}$ of measured refl. & 41,601 \\
$\mathrm{~N}^{\circ}$ of observed refl. $\left(\mathrm{F}^{2}>4 \sigma(\mathrm{F})\right)$ & 19,558 \\
$\mathrm{R}\left(\mathrm{F}^{2}>4 \sigma(\mathrm{F})\right)$ & 0.0806 \\
wR $($ all reflections $)$ & 0.2774 \\
$\mathrm{Gof}$ & 0.998 \\
$\Delta \rho$ max $\left(\mathrm{e} \AA^{-3}\right)$ & 1.022 \\
$\Delta \rho$ min $\left(\mathrm{e} \AA^{-3}\right)$ & -1.152 \\
\hline &
\end{tabular}


Table 2

Selected distances $(\AA)$ and angles $\left({ }^{\circ}\right)$ around the copper atoms for complex 2.

\begin{tabular}{|c|c|c|}
\hline $\mathrm{Cu}(1)-\mathrm{O}(37) 2.218(5)$ & $\mathrm{O}(37)-\mathrm{Cu}(1)-\mathrm{O}(38) 94.1(2)$ & $\mathrm{O}(1)-\mathrm{Cu}(2)-\mathrm{O}(39) 95.1(3)$ \\
\hline $\mathrm{Cu}(1)-\mathrm{O}(38) 2.049(7)$ & $\mathrm{O}(37)-\mathrm{Cu}(1)-\mathrm{N}(1)$ 110.71(18) & $\mathrm{O}(1)-\mathrm{Cu}(2)-\mathrm{N}(4) 116.0(2)$ \\
\hline $\mathrm{Cu}(1)-\mathrm{N}(1) 2.113(5)$ & $\mathrm{O}(37)-\mathrm{Cu}(1)-\mathrm{N}(2) 91.30(19)$ & $\mathrm{O}(1)-\mathrm{Cu}(2)-\mathrm{N}(5) 91.6(3)$ \\
\hline $\mathrm{Cu}(1)-\mathrm{N}(2) 2.003(5)$ & $\mathrm{O}(37)-\mathrm{Cu}(1)-\mathrm{N}(3) 94.0(2)$ & $\mathrm{O}(1)-\mathrm{Cu}(2)-\mathrm{N}(6) 91.4(3)$ \\
\hline $\mathrm{Cu}(1)-\mathrm{N}(3) 2.006(7)$ & $\mathrm{O}(38)-\mathrm{Cu}(1)-\mathrm{N}(1) 154.8(2)$ & $\mathrm{O}(39)-\mathrm{Cu}(2)-\mathrm{N}(4) 148.8(2)$ \\
\hline $\mathrm{Cu}(2)-\mathrm{O}(1) 2.186(5)$ & $\mathrm{O}(38)-\mathrm{Cu}(1)-\mathrm{N}(2) 87.0(2)$ & $\mathrm{O}(39)-\mathrm{Cu}(2)-\mathrm{N}(5) 87.0(3)$ \\
\hline $\mathrm{Cu}(2)-\mathrm{O}(39) 2.077(4)$ & $\mathrm{O}(38)-\mathrm{Cu}(1)-\mathrm{N}(3) 85.3(3)$ & $\mathrm{O}(39)-\mathrm{Cu}(2)-\mathrm{N}(6) 85.7(3)$ \\
\hline $\mathrm{Cu}(2)-\mathrm{N}(4) 2.111(5)$ & $\mathrm{N}(1)-\mathrm{Cu}(1)-\mathrm{N}(2) 96.2(2)$ & $\mathrm{N}(4)-\mathrm{Cu}(2)-\mathrm{N}(5) 88.9(3)$ \\
\hline $\mathrm{Cu}(2)-\mathrm{N}(5) 1.998(7)$ & $\mathrm{N}(1)-\mathrm{Cu}(1)-\mathrm{N}(3) 88.8(2)$ & $\mathrm{N}(4)-\mathrm{Cu}(2)-\mathrm{N}(6) 96.1(2)$ \\
\hline $\mathrm{Cu}(2)-\mathrm{N}(6) 2.011(7)$ & $\mathrm{N}(2)-\mathrm{Cu}(1)-\mathrm{N}(3) 171.0(2)$ & $\mathrm{N}(5)-\mathrm{Cu}(2)-\mathrm{N}(6) 172.4(3)$ \\
\hline $\mathrm{Cu}(3)-\mathrm{O}(4) 2.242(5)$ & $\mathrm{O}(4)-\mathrm{Cu}(3)-\mathrm{O}(40) 94.8(2)$ & $\mathrm{O}(7)-\mathrm{Cu}(4)-\mathrm{O}(41) 92.8(2)$ \\
\hline $\mathrm{Cu}(3)-\mathrm{O}(40) 2.088(7)$ & $\mathrm{O}(4)-\mathrm{Cu}(3)-\mathrm{N}(7) 104.7(2)$ & $\mathrm{O}(7)-\mathrm{Cu}(4)-\mathrm{N}(10) 110.6(2)$ \\
\hline $\mathrm{Cu}(3)-\mathrm{N}(7) 2.111(7)$ & $\mathrm{O}(4)-\mathrm{Cu}(3)-\mathrm{N}(8) 91.4(3)$ & $\mathrm{O}(7)-\mathrm{Cu}(4)-\mathrm{N}(11) 91.2(2)$ \\
\hline $\mathrm{Cu}(3)-\mathrm{N}(8) 1.991(7)$ & $\mathrm{O}(4)-\mathrm{Cu}(3)-\mathrm{N}(9) 95.8(2)$ & $\mathrm{O}(7)-\mathrm{Cu}(4)-\mathrm{N}(12) 93.8(2)$ \\
\hline $\mathrm{Cu}(3)-\mathrm{N}(9) 1.977(6)$ & $\mathrm{O}(40)-\mathrm{Cu}(3)-\mathrm{N}(7)$ 159.7(2) & $\mathrm{O}(41)-\mathrm{Cu}(4)-\mathrm{N}(10) 156.2(3)$ \\
\hline $\mathrm{Cu}(4)-\mathrm{O}(7) 2.236(5)$ & $\mathrm{O}(40)-\mathrm{Cu}(3)-\mathrm{N}(8) 87.0(3)$ & $\mathrm{O}(41)-\mathrm{Cu}(4)-\mathrm{N}(11) 87.1(3)$ \\
\hline $\mathrm{Cu}(4)-\mathrm{O}(41) 2.055(4)$ & $\mathrm{O}(40)-\mathrm{Cu}(3)-\mathrm{N}(9) 85.2(2)$ & $\mathrm{O}(41)-\mathrm{Cu}(4)-\mathrm{N}(12) 85.9(2)$ \\
\hline $\mathrm{Cu}(4)-\mathrm{N}(10) 2.108(5)$ & $\mathrm{N}(7)-\mathrm{Cu}(3)-\mathrm{N}(8) 98.0(3)$ & $\mathrm{N}(10)-\mathrm{Cu}(4)-\mathrm{N}(11) 88.2(3)$ \\
\hline $\mathrm{Cu}(4)-\mathrm{N}(11) 1.990(7)$ & $\mathrm{N}(7)-\mathrm{Cu}(3)-\mathrm{N}(9) 87.1(2)$ & $\mathrm{N}(10)-\mathrm{Cu}(4)-\mathrm{N}(12) 96.4(2)$ \\
\hline $\mathrm{Cu}(4)-\mathrm{N}(12) 2.018(6)$ & $\mathrm{N}(8)-\mathrm{Cu}(3)-\mathrm{N}(9) 169.8(2)$ & $\mathrm{N}(11)-\mathrm{Cu}(4)-\mathrm{N}(12) 171.6(2)$ \\
\hline $\mathrm{Cu}(5)-\mathrm{O}(10) 2.265(7)$ & $\mathrm{O}(10)-\mathrm{Cu}(5)-\mathrm{O}(42) 94.6(2)$ & $\mathrm{O}(43)-\mathrm{Cu}(6)-\mathrm{O}(44) 89.9(2)$ \\
\hline $\mathrm{Cu}(5)-\mathrm{O}(42) 2.029(5)$ & $\mathrm{O}(10)-\mathrm{Cu}(5)-\mathrm{N}(13) 106.3(2)$ & $\mathrm{O}(43)-\mathrm{Cu}(6)-\mathrm{N}(16) 161.6(2)$ \\
\hline $\mathrm{Cu}(5)-\mathrm{N}(13) 2.114(5)$ & $\mathrm{O}(10)-\mathrm{Cu}(5)-\mathrm{N}(14) 94.0(3)$ & $\mathrm{O}(43)-\mathrm{Cu}(6)-\mathrm{N}(17) 88.0(3)$ \\
\hline $\mathrm{Cu}(5)-\mathrm{N}(14) 1.985(6)$ & $\mathrm{O}(10)-\mathrm{Cu}(5)-\mathrm{N}(15) 89.3(3)$ & $\mathrm{O}(43)-\mathrm{Cu}(6)-\mathrm{N}(18) 85.3(3)$ \\
\hline $\mathrm{Cu}(5)-\mathrm{N}(15) 1.999(7)$ & $\mathrm{O}(42)-\mathrm{Cu}(5)-\mathrm{N}(13) 159.0(2)$ & $\mathrm{O}(44)-\mathrm{Cu}(6)-\mathrm{N}(16) 107.7(2)$ \\
\hline $\mathrm{Cu}(6)-\mathrm{O}(43) 2.068(7)$ & $\mathrm{O}(42)-\mathrm{Cu}(5)-\mathrm{N}(14) 87.4(2)$ & $\mathrm{O}(44)-\mathrm{Cu}(6)-\mathrm{N}(17) 92.7(2)$ \\
\hline $\mathrm{Cu}(6)-\mathrm{O}(44) 2.214(5)$ & $\mathrm{O}(42)-\mathrm{Cu}(5)-\mathrm{N}(15) 85.8(3)$ & $\mathrm{O}(44)-\mathrm{Cu}(6)-\mathrm{N}(18) 96.7(2)$ \\
\hline $\mathrm{Cu}(6)-\mathrm{N}(16) 2.112(5)$ & $\mathrm{N}(13)-\mathrm{Cu}(5)-\mathrm{N}(14) 88.7(2)$ & $\mathrm{N}(16)-\mathrm{Cu}(6)-\mathrm{N}(17) 96.3(2)$ \\
\hline $\mathrm{Cu}(6)-\mathrm{N}(17) 2.015(7)$ & $\mathrm{N}(13)-\mathrm{Cu}(5)-\mathrm{N}(15) 96.7(2)$ & $\mathrm{N}(16)-\mathrm{Cu}(6)-\mathrm{N}(18) 87.4(2)$ \\
\hline $\mathrm{Cu}(6)-\mathrm{N}(18) 2.002(7)$ & $\mathrm{N}(14)-\mathrm{Cu}(5)-\mathrm{N}(15) 172.6(2)$ & $\mathrm{N}(17)-\mathrm{Cu}(6)-\mathrm{N}(18) 168.4(3)$ \\
\hline
\end{tabular}

was isolated as green crystals, as previously reported [15], at $\mathrm{pH} 7.5$. Calc. for $\mathrm{C}_{12} \mathrm{H}_{16} \mathrm{~N}_{4} \mathrm{CuCl}_{2} \mathrm{O}_{9}(\mathrm{FW}=494.73 \mathrm{~g} / \mathrm{mol})$ : $\mathrm{C}, 29.14 ; \mathrm{H}, 3.26$; $\mathrm{N}$, 11.33; $\mathrm{Cu}, 12.83 \%$; Experim. values: C, 29.26; $\mathrm{H}, 3.50 ; \mathrm{N}, 11.30 ; \mathrm{Cu}$, $12.63 \%$. UV-vis bands, $\lambda_{\max }, \mathrm{nm}\left(\varepsilon, 10^{3} \mathrm{M}^{-1} \mathrm{~cm}^{-1}\right): 208$ (31.5), $277 \mathrm{~s}$ (4.1), 285 (8.0), $295 \mathrm{~s}$ (5.8), 632 (0.084).

\subsubsection{Complex $\left.\left[\mathrm{Cu}_{2} \text { (apyhist) }\right)_{2} \mathrm{dpam}\right]\left(\mathrm{ClO}_{4}\right)_{4} 4$}

At first, the precursor complex $\mathbf{3}$ was prepared as described above, followed by the addition of stoichiometric amounts of the bridge-ligand 2,2'-bis(aminomethyl)diphenyl (dpam). After a while, brownish-violet crystals of the resulting dinuclear species were collected, washed with cold methanol, and dried in desiccator, under low pressure. Calc. for $\mathrm{C}_{38} \mathrm{H}_{44} \mathrm{~N}_{10} \mathrm{Cu}_{2} \mathrm{Cl}_{4} \mathrm{O}_{16}$ (FW $=1165.72 \mathrm{~g} / \mathrm{mol}$ ): $\mathrm{C}, 39.15 ; \mathrm{H}, 3.80 ; \mathrm{N}$, 12.02; $\mathrm{Cu}, 10.90 \%$; Experim. values: C, 39.45; H, 3.83; N, 11.48; Cu, 11.09\%. UV-vis bands, $\lambda_{\max }, \mathrm{nm}\left(\varepsilon, 10^{3} \mathrm{M}^{-1} \mathrm{~cm}^{-1}\right): 277 \mathrm{~s}(16.0), 285$ (18.0), 295 s (14.0), 510 (0.48), 664 (0.175).

\subsection{Physical methods}

Elemental analyses of all the prepared compounds were performed at Central Analítica of USP, using a CNH 2400 Perkin-Elmer instrument. Analyses of copper were done by ICP-OES, in a Spectro instrument, model Arcos-FHS12. Electronic spectra were recorded in a UV-1650PC spectrophotometer from Shimadzu, using quartz cells with de $1.000 \mathrm{~cm}$ optical length, and solutions of the diverse complexes in the range $10^{-4}$ to $10^{-3} \mathrm{M}$. Vibrational spectra in the infrared region were registered in a FT-ABB Bomen instrument model MB, by diffuse reflectance, in the range $400-4000 \mathrm{~cm}^{-1}$. The samples were prepared in $\mathrm{KBr}$ pellets ( $20 \mathrm{mg}$ complex/200 $\mathrm{mg} \mathrm{KBr})$, previously dried at $120{ }^{\circ} \mathrm{C}$. EPR spectra were recorded in a Bruker EMX instrument, working at X-band ( $9.65 \mathrm{GHz}$ frequency, $20 \mathrm{~mW}$ power, $100 \mathrm{kHz}$ modulation frequency). DPPH ( $\alpha, \alpha^{\prime}$-diphenyl- $\beta$-picrylhydrazyl) was used as magnetic field calibrator ( $g=2.0036)$, and measurements were carried out with solid samples or frozen acetone- or acetonitrile-aqueous solutions of the different complexes, in Wilmad quartz tubes ( $4 \mathrm{~mm}$ internal diameter). Usually, $15 \mathrm{G}$ modulation amplitude, $7.96 \times 10^{3}$ or $3.56 \times 10^{4}$ receiver gain, and 2 or 4 scans were standard conditions for the spectra recording, at $77 \mathrm{~K}$.

\subsection{Relative thermodynamic stability of the complexes}

The relative stability of the complexes was estimated in titration experiments, using HSA as competitive ligand, in similar procedures already reported [16]. CD spectra were recorded in a JASCO J-720 spectropolarimeter, using a quartz cuvette of $0.1 \mathrm{~cm}$ path length, at room temperature, in the range $200-300 \mathrm{~nm}$ or $350-650 \mathrm{~nm}$. The initial experimental HSA concentration was 500 or $700 \mu \mathrm{M}$, and the spectra were registered in phosphate buffer $(50 \mathrm{mM}, \mathrm{pH} 7.4)$ containing $\mathrm{NaCl}$ $0.1 \mathrm{M}$, in the absence or in the presence of increasing amounts of each complex studied, up to 1:2 stoichiometric ratio. By considering the competitive equilibria:

\begin{tabular}{cc}
{$[\mathrm{CuL}] \rightleftarrows \mathrm{Cu}+\mathrm{L}$} & $1 / \mathrm{K}_{[\mathrm{CuL}]}$ \\
$\mathrm{Cu}+\mathrm{HSA} \rightleftarrows[\mathrm{Cu}(\mathrm{HSA})]$ & $\mathrm{K}_{[\mathrm{Cu}(\mathrm{HSA})]}$ \\
\hline$[\mathrm{CuL}]+\mathrm{HSA} \rightleftarrows[\mathrm{Cu}(\mathrm{HSA})]+\mathrm{L}$ & $\mathrm{K}=\mathrm{K}_{[\mathrm{Cu}(\mathrm{HSA})]} / \mathrm{K}_{[\mathrm{CuL}]}$
\end{tabular}

Table 3

Geometric parameters reflecting the flexibility of complex 2

\begin{tabular}{|c|c|c|c|c|c|}
\hline \multirow{2}{*}{$\begin{array}{l}\text { Coordination type } \\
\left(\mathrm{OTf}, \mathrm{H}_{2} \mathrm{O}\right)\left(\mathrm{H}_{2} \mathrm{O}, \mathrm{H}_{2} \mathrm{O}\right)\end{array}$} & \multicolumn{2}{|c|}{$\begin{array}{l}\text { Angle of the diphenyl ( }{ }^{\circ} \text {, angle of the } 2 \\
\text { planes around the selected bond) }\end{array}$} & \multicolumn{2}{|c|}{$\mathrm{Cu}-\mathrm{Cu}$ distance $(\AA)$} & \multirow{2}{*}{$\begin{array}{l}\tau \text { parameter } \\
0.27 / 0.39\end{array}$} \\
\hline & $\mathrm{C} 21-\mathrm{C} 22$ & 64.1 & $\mathrm{Cu} 1-\mathrm{Cu} 2$ & 7.65 & \\
\hline$\left(\mathrm{OTf}, \mathrm{H}_{2} \mathrm{O}\right)\left(\mathrm{H}_{2} \mathrm{O}, \mathrm{H}_{2} \mathrm{O}\right)$ & C105-C106 & 64.9 & $\mathrm{Cu} 5-\mathrm{Cu} 6$ & 7.82 & $0.23 / 0.12$ \\
\hline$\left(\mathrm{OTf}, \mathrm{H}_{2} \mathrm{O}\right)\left(\mathrm{OTf}, \mathrm{H}_{2} \mathrm{O}\right)$ & C63-C64 & 67.2 & $\mathrm{Cu} 3-\mathrm{Cu} 4$ & 8.36 & $0.17 / 0.27$ \\
\hline
\end{tabular}




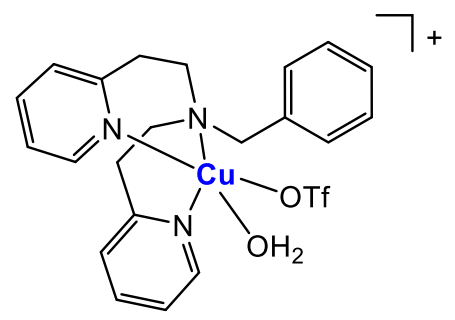

$[\mathrm{Cu}(\mathrm{N} 22)]^{+}$1, OTf $=\mathrm{CF}_{3} \mathrm{SO}_{3}^{-}$

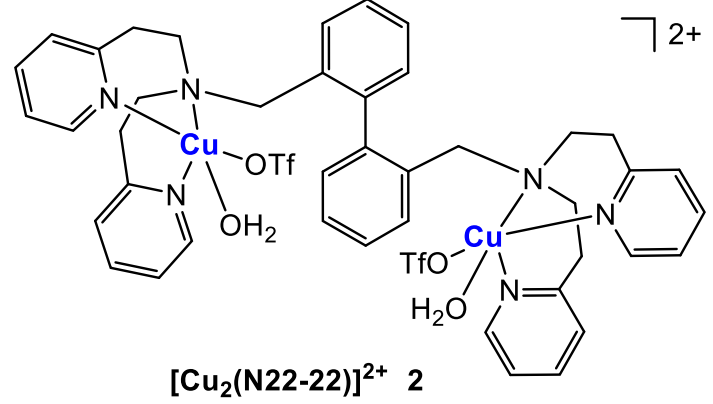

$\left[\mathrm{Cu}_{2}(\mathrm{~N} 22-22)\right]^{2+} 2$<smiles></smiles>

$\left[\mathrm{Cu}\left(\text { apyhist) } \mathrm{H}_{2} \mathrm{O}\right]^{2+} 3\right.$

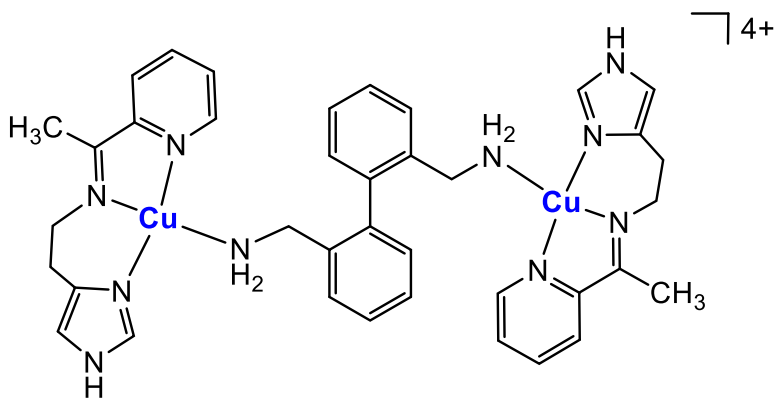

[Cu ${ }_{2}$ (apyhist) ${ }_{2}$ dpam] 4 dpam = diphenyl-2,2'-aminomethyl

Fig. 1. Structures of the studied copper(II) complexes.

and stoichiometric relations of the reagents, the $\mathrm{K}_{[\mathrm{CuL}]}$ for each complex could be determined, since the corresponding constant for copper ion inserted at $\mathrm{N}$-terminal site of the protein is known. The reported value for insertion of copper ions at the selective $\mathrm{N}$-terminal metal binding site of HSA is $\log \mathrm{K}_{[\mathrm{Cu}(\mathrm{HSA})]} 12.0$ [17]. Copper-aqua species was used in control experiments, to obtain standard curve of CD band intensity vs. [Cu(HSA)] formed (see Supplementary Information, Fig. S1).

\subsection{Kinetic experiments of tyrosinase activity}

The catalytic activity of both dinuclear copper(II) complexes 2 and 4 in the oxidation of $L$-dopa was verified in phosphate buffer $(50 \mathrm{mM}$, $\mathrm{pH}=7.00$ ), at $25^{\circ} \mathrm{C}$. The activities of the corresponding mononuclear compounds 1 and $\mathbf{3}$ were also measured for comparison. The experimental conditions used in these experiments were: [L-dopa] $=$ $8.0 \mathrm{mM}$, [CuL] in the range 1 to $400 \mu \mathrm{M}$; or $[\mathrm{CuL}]=160 \mathrm{mM}$ (for dinuclear species) and $320 \mathrm{mM}$ (for mononuclear species), for [L-dopa] in the range 4.0 to $8.0 \mathrm{mM}$. From curves of increasing absorbance versus concentration, monitored at $475 \mathrm{~nm}$, the pseudo-first- and secondorder kinetic constants were then determined from graphics of initial rate of the corresponding dopaquinone formation $v$ s. concentration of the catalyst, or of the substrate.

\subsection{DNA cleavage after incubation with the copper(II) complexes}

Since in many cases DNA is an important target for potential antitumor agents, the copper complexes studied had also their nuclease activity compared. Single and double DNA strand cleavages were monitored by electrophoresis experiments, in agarose gel. The plasmid pBluescript II (Stratagene) was purified using Qiagen plasmid purification kit (Qiagen). Reaction mixtures ( $20 \mu \mathrm{L}$ total volume) containing $240 \mathrm{ng}$ of supercoiled

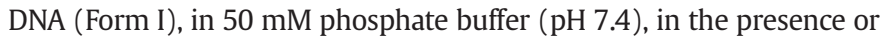
absence of $120 \mu \mathrm{M}$ of $\mathrm{H}_{2} \mathrm{O}_{2}$, with concentrations of copper(II) complexes 1-4, varying in the range 1 to $50 \mu \mathrm{M}$, were incubated at $37^{\circ} \mathrm{C}$ for different periods of time. After incubation, a quench buffer solution ( $4 \mu \mathrm{L}, 15 \%$ Ficoll (type 400) in water; 0,25\% bromophenol blue) was added, and the final solution was subjected to electrophoresis on an $1 \%$ agarose gel in $1 \times$
TAE buffer ( $40 \mathrm{mM}$ Tris-acetate, $1 \mathrm{mM}$ EDTA) at $100 \mathrm{~V}$, for $2 \mathrm{~h}$. The electrophoresis was performed in a Gibco Horizon 11-14 Gel Electrophoresis System at $100 \mathrm{~V}$.

\subsection{Cell treatment}

B16F10 and TM1MNG3 were used as melanoma cell models. B16F10 is a well-known murine melanoma cell lineage, and TM1MNG3 is a melan-a-derived melanoma clone, which has already shown to be susceptible to another copper(II) complex, $\left[\mathrm{Cu}(\text { isaepy) }]^{2+}\right.$, related to the present study [18]. The copper(II) complexes studied [Cu(N22) $\left.\left(\mathrm{H}_{2} \mathrm{O}\right) \mathrm{OTf}\right]^{+},\left[\mathrm{Cu}_{2}(\mathrm{~N} 22-22)\left(\mathrm{H}_{2} \mathrm{O}\right)_{2}(\mathrm{OTf})_{2}\right]^{2+},\left[\mathrm{Cu}(\text { apyhist }) \mathrm{H}_{2} \mathrm{O}\right]^{2+}$, or

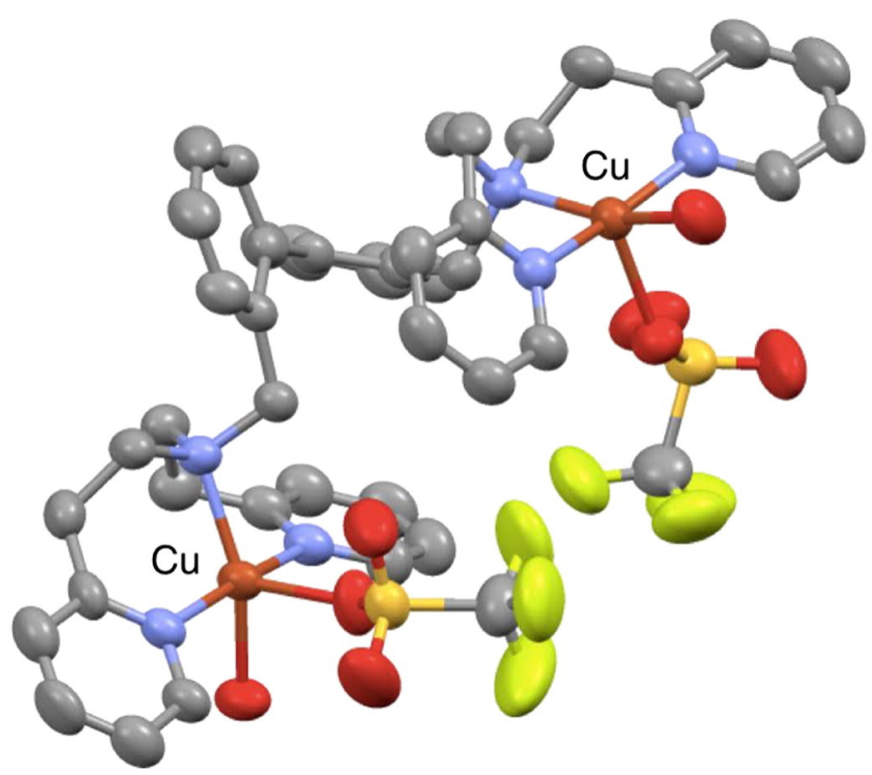

Fig. 2. Ortep view of one of the three independent dinuclear copper complexes $\mathbf{2}$ in the asymmetric unit. 
Table 4

EPR parameters ( $\mathrm{g}$ and hyperfine constant A values) of copper(II) complexes samples in solid state, and in frozen acetonitrile-aqueous solution, at $77 \mathrm{~K}$. The data for the aquacomplex was included for comparison.

\begin{tabular}{|c|c|c|c|c|c|c|}
\hline \multirow[b]{2}{*}{ Complexes } & \multicolumn{2}{|c|}{ Solid samples } & \multicolumn{4}{|c|}{ Frozen solutions } \\
\hline & $\mathrm{g}_{\perp}$ & $\mathrm{g}_{/ /}$ & $g_{\perp}$ & $\mathrm{g}_{/ /}$ & $\mathrm{A}_{/ / /}, 10^{-4} \mathrm{~cm}^{-1 \mathrm{a}}$ & $\mathrm{g}_{/ / /} / \mathrm{A}_{/ /}, \mathrm{cm}$ \\
\hline 1 & \multicolumn{2}{|c|}{$2.125\left(\mathrm{~g}_{\text {iso }}\right)$} & 2.071 & 2.253 & 152 & 148 \\
\hline 2 & \multicolumn{2}{|c|}{$2.094\left(\mathrm{~g}_{\text {iso }}\right)$} & 2.078 & 2.227 & 166 & 134 \\
\hline 3 & 2.060 & 2.208 & 2.062 & 2.259 & 177 & 128 \\
\hline 4 & 2.061 & 2.206 & 2.081 & 2.225 & 182 & 122 \\
\hline$\left[\mathrm{Cu}\left(\mathrm{H}_{2} \mathrm{O}\right)_{4}\right]^{2+}$ & & & 2.075 & 2.361 & 154 & 153 \\
\hline
\end{tabular}

${ }^{\text {a }} \mathrm{A}_{/ /}\left(\times 10^{-4} \mathrm{~cm}^{-1}\right)=0.46686 \times 10^{-4} \mathrm{~g}_{/ /} \mathrm{A}_{/ /}(\mathrm{G})$.

$\left.\left[\mathrm{Cu}_{2} \text { (apyhist }\right)_{2}(\mathrm{dpam})\right]^{4+}$ were used to treat the cells. Stock solutions of these complexes ( $5 \mathrm{mM}$ ) were prepared in 10\% DMSO and were stored at $-20{ }^{\circ} \mathrm{C}$. These solutions were diluted in buffer to their final concentrations immediately before the experiments. An aqueous DMSO solution, corresponding to the highest DMSO concentration $(0.1 \%)$ in the complex solutions, was employed as a vehicle control. Typically, the cells were plated and then treated with the metal complexes for $24 \mathrm{~h}$ (or for the specified time) after they had adhered to the plate (usually $4 \mathrm{~h}$ later). Experiments were carried out at least in triplicates.

\subsection{Cellular viability of B16F10 and TM1MNG3 melanoma cells in the presence of copper(II) complexes}

Cells were plated at a density of $10^{4}$ cells/well in a 96-well microplate. Twenty-four hours after treatment with the metal complexes, the cells were washed and incubated with $200 \mu \mathrm{L}$ of $0.5 \mathrm{mg} / \mathrm{mL}$ MTT
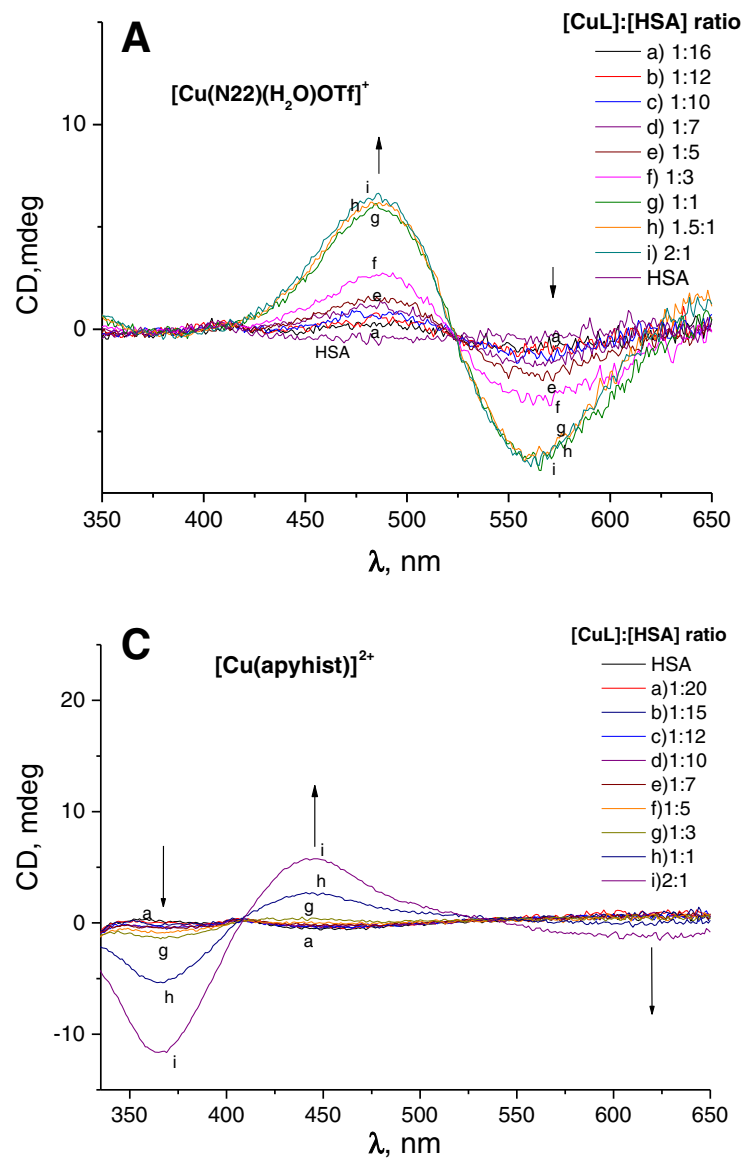

Table 5

Relative stability constants of the copper(II) complexes studied, as determined in competitive experiments towards HSA by CD spectroscopy. Copper-aqua species was used in control experiments, to obtain standard curve.

\begin{tabular}{lll}
\hline Complex & & $\log \mathrm{K}_{[\mathrm{CuL}]}$ \\
\hline $\mathbf{1}$ & {$\left[\mathrm{Cu}(\mathrm{N} 22)\left(\mathrm{H}_{2} \mathrm{O}\right) \mathrm{OTf}\right]^{+}$} & 12.4 \\
$\mathbf{2}$ & {$\left[\mathrm{Cu}_{2}(\mathrm{~N} 22-22)\left(\mathrm{H}_{2} \mathrm{O}\right)_{2}(\mathrm{OTf})_{2}\right]^{2+}$} & 12.0 \\
$\mathbf{3}$ & {$\left[\mathrm{Cu}(\text { apyhist }) \mathrm{H}_{2} \mathrm{O}\right]^{2+}$} & $\mathrm{a}$ \\
$\mathbf{4}$ & {$\left[\mathrm{Cu}_{2}(\right.$ apyhist } & $\mathrm{dpam})]^{4+}$ \\
& {$[\mathrm{Cu}(\mathrm{HSA})]^{\mathrm{b}}$} & $\mathrm{a}$ \\
& & 12.0 \\
\hline
\end{tabular}

a The main interaction in this case occurred at Cys34, a secondary site (Ref. [25]).

b Copper(II) inserted at the primary N-terminal site of the protein (Ref. [17]).

solution, for $3 \mathrm{~h}$ in a $\mathrm{CO}_{2}$ incubator. The cells were then washed, and formazan crystals were extracted with $200 \mu \mathrm{L}$ of DMSO. The absorbance was read at $570 \mathrm{~nm}$ in a microplate reader (BioRad, Hercules, CA, USA). Results are average values obtained from 7 (for B16F10) or 4 (for TM1MNG3) independent experiments, considering the values obtained for control as $100 \%$.

\section{Results and discussion}

All the copper(II) complexes studied were obtained in good yields and high purity, as attested by elemental analysis data (see Experimental section), and corroborated by spectroscopic data. For complexes $\mathbf{1}$ and $\mathbf{2}$, the corresponding ligands N22 and N22-N22 were previously prepared and then metallated. Complex $\mathbf{2}$ crystallized as three independent dinuclear copper complexes in an asymmetric unit. In each complex the copper are penta-coordinated in a square-based pyramidal geometry more or less distorted: the Addison $\tau$ parameter [19] ranges from $0.12 \AA$ to
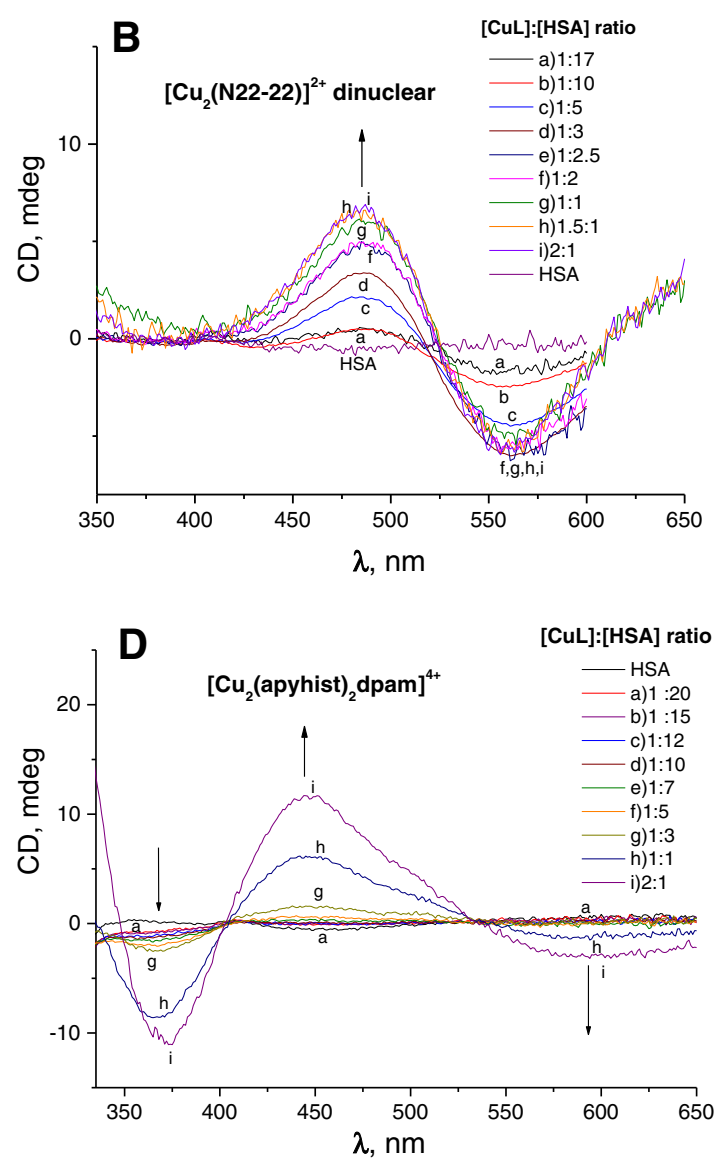

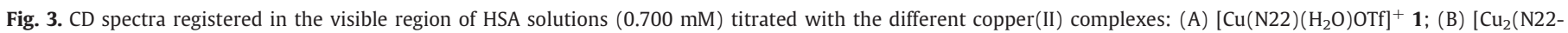
$\left.22)\left(\mathrm{H}_{2} \mathrm{O}\right)_{2}(\mathrm{OTf})_{2}\right]^{2+} \mathbf{2}$; (C) $\left[\mathrm{Cu}(\text { apyhist }) \mathrm{H}_{2} \mathrm{O}\right]^{2+} \mathbf{3}$ and (D) $\left.\left[\mathrm{Cu}_{2} \text { (apyhist) }\right)_{2} \mathrm{dpam}\right]^{4+}$, in phosphate buffer (50 mM, pH 7.4), at room temperature. 
0.39 A. Each copper is coordinated to the three nitrogen atoms of the pyridylalkylamin moieties of the ligand, the remaining sites being occupied by either two water molecules or one water molecule and one trifluoromethane sulfonate counter-ion (Fig. 2). The flexibility of the diphenyl spacer of the ligand allows a wide variation for the $\mathrm{Cu}-\mathrm{Cu}$ distances, which are equal to $7.650 \AA$, $7.817 \AA$ and $8.363 \AA$ for each complex, respectively.

Complex 3 synthesis has been already described [15]. The corresponding dinuclear species $\mathbf{4}$ was obtained from this complex $\mathbf{3}$, by adding stoichiometric amounts of the bridge-ligand, dpam (see Fig. 1). The characterization of all these complexes was provided by different spectroscopic techniques. Characteristic bands of the metal coordinated species, related to internal ligand, charge transfer or $\mathrm{d}$ - $\mathrm{d}$ transitions were observed by electronic spectroscopy, as specified in the Experimental section. Particularly, d-d bands were observed at $684 \mathrm{~nm}$ for complexes 1 and 2 , with absorptivity values $0.142 \times 10^{3}$ and $0.275 \times 10^{3} \mathrm{M}^{-1} \mathrm{~cm}^{-1}$, respectively. For complex 3, this band occurred at $632 \mathrm{~nm}(\varepsilon=$ $\left.0.084 \times 10^{3} \mathrm{M}^{-1} \mathrm{~cm}^{-1}\right)$, and for complex 4 at $664 \mathrm{~nm}(\varepsilon=0.175 \times$ $10^{3} \mathrm{M}^{-1} \mathrm{~cm}^{-1}$ ). EPR spectra in frozen solution, indicated that the environment around copper ion is not very different in all of them, with spectroscopic parameters, $g$ and A values consistent with a pentacoordinated (in the case of complexes $\mathbf{1}$ and $\mathbf{2}$ ), or a tetragonal configuration showing some tetrahedral distortion (for complexes $\mathbf{3}$ and $\mathbf{4}$ ), as shown in Table 4. Considering the quotient $\mathrm{g}_{/ /} / \mathrm{A}_{/ /}$determined from EPR data, usually used to evaluate this distortion in copper centers [20], the dinuclear species show a more tetragonal structure than the corresponding mononuclear ones, in both cases. Complex $\mathbf{4}$ showed the more planar environment around the metal ion in this series, as expected, since its imine tridentate ligand provide a more rigid coordination structure around the copper ion.

\subsection{Estimation of relative stability of the complexes by $C D$}

By considering competitive equilibria of copper ions coordinated to each ligand in the studied complexes, or inserted at $\mathrm{N}$-terminal site of HSA, it was achieved an estimation of the apparent stability of complexes $\mathbf{1}$ and 2, according to procedures already described [16]. Titrations of a protein solution with each copper(II) complex, monitored through CD spectra at the characteristic band at $564 \mathrm{~nm}$, attributed to the insertion of a copper ion at the selective N-terminal metal binding site of the protein [17], were carried out with this purpose. In Fig. 3, the corresponding titration curves are shown. The determined values for $\log \mathrm{K}_{[\mathrm{CuL}]}$ were based on the rising of this band, up to $1: 1$ stoichiometric ratio [HSA]:[CuL], and they are of the same order as log $\mathrm{K}_{[\mathrm{Cu}(\mathrm{HSA})]}$ reported in the literature [17,21], as shown in Table 5. An additional raising band around $700 \mathrm{~nm}$ was observed for both complexes, when excess of copper (up to 1:2) was added, attributed to a second copper ion insertion, probably at a multimetal binding site, described as composed by His67, His247, Asn99 and Asp249 [22]. Calibration curve was provided by similar titration experiments of HSA with the aqua-copper(II) complex (see Fig. S1).

In contrast, complexes $\mathbf{3}$ and $\mathbf{4}$ interacted only at a secondary metal binding site of HSA, monitored by a growing band at $370 \mathrm{~nm}$, and identified as the Cys34 pocket [23,24]. It has been previously observed that even when this Cys34 is blocked, after previous treatment of the protein with N-ethyl-maleimide, complex 3 does not insert copper at the primary usual metal binding site of the protein [25]. Therefore, complex 4 presented here the same behavior as complex $\mathbf{3}$, attesting an interaction involving probably molecular recognition of the imine ligand apyhist at the Cys34 site of the protein [25].

Complementary measurements, monitoring the $\mathrm{CD}$ band at $208 \mathrm{~nm}$ attributed to the $\alpha$-helix content of the protein, indicated that none of the complexes was able to disturb the protein secondary structure, modifying significantly its ellipticity (see Fig. S2).

\subsection{Tyrosinase activity}

The catalytic activities of all the studied complexes were verified, using $L$-dopa as the substrate to be oxidized. Comparative curves of absorbance increasing values, attributed to the formation of quinone product, are shown in Fig. 4A. Typical curves with a saturation effect (Michaelis-Menten mechanism) attested that as expected the dinuclear complexes are more active as tyrosinase mimics than the analogous mononuclear species, although all of them are much less active than the tyrosinase protein [26]. Also, complex $\mathbf{2}$ with a more flexible ligand, is much more effective than complex 4 . The dependence of initial $L$-dopa

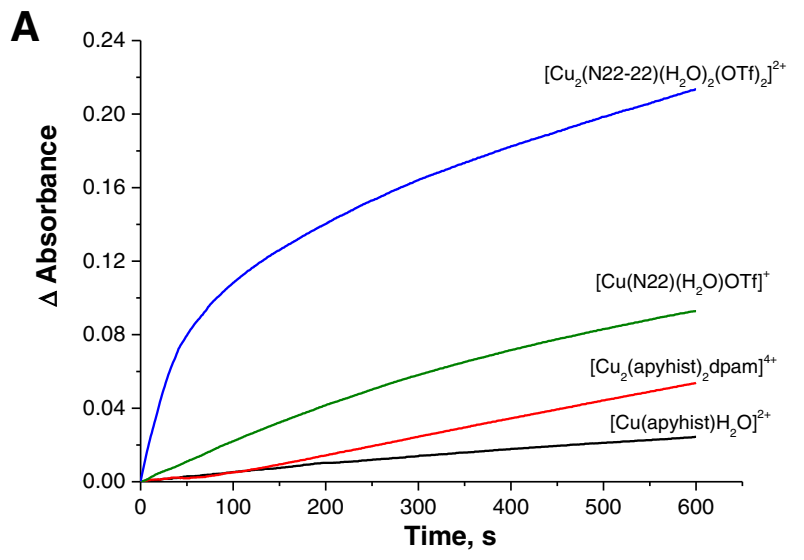

B
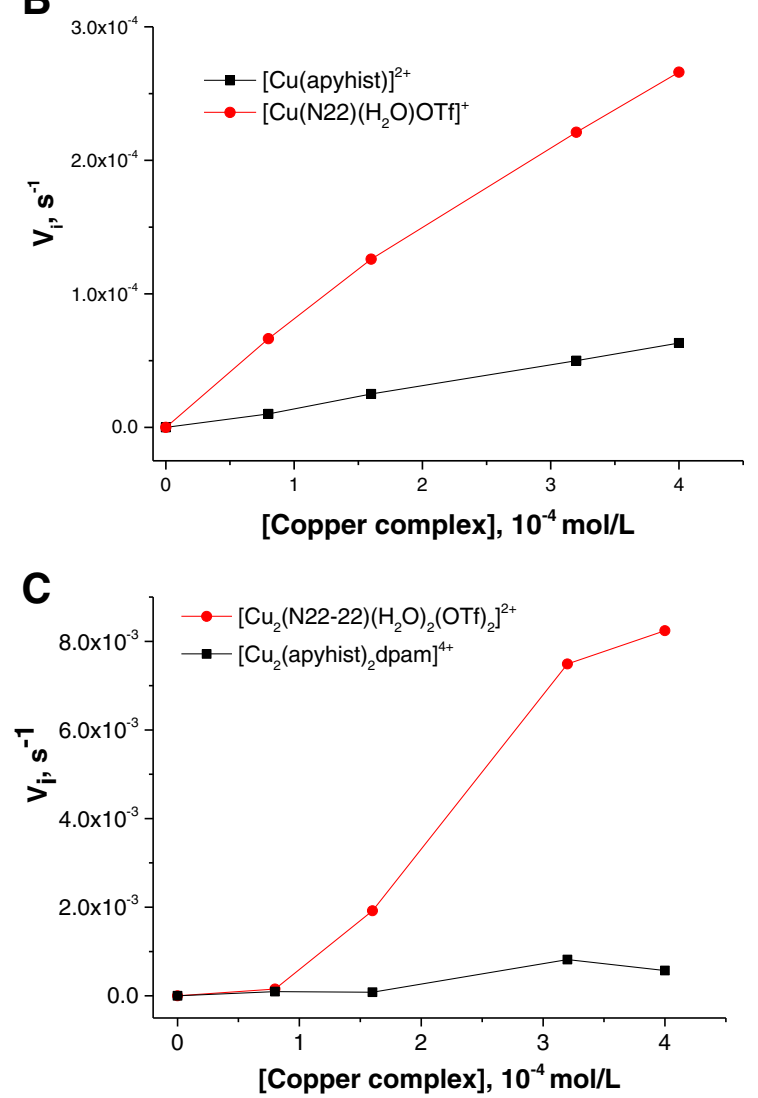

Fig. 4. A) Comparative curves (Absorbance vs. time) of catalytic activity of studied copper(II) complexes in the oxidation of $L$-dopa $(8.0 \mathrm{mM})$, at concentrations $160 \mu \mathrm{M}$ (dinuclear species) and $320 \mu \mathrm{M}$ (mononuclear species). Reaction at $25{ }^{\circ} \mathrm{C}$, in phosphate buffer ( $50 \mathrm{mM}, \mathrm{pH}=7.0$ ), monitored by dopaquinone formation, at $475 \mathrm{~nm}$; B) Dependence of L-dopa initial oxidation rate on increasing concentrations of complexes, $\left[\mathrm{Cu}(\mathrm{N} 22)\left(\mathrm{H}_{2} \mathrm{O}\right) \mathrm{OTf}\right]^{+}$ 1 and $\left[\mathrm{Cu}(\text { apyhist }) \mathrm{H}_{2} \mathrm{O}\right]^{2+}$ 3; C) Dependence of $L$-dopa initial oxidation rate on increasing concentrations of complexes, $\left[\mathrm{Cu}_{2}(\mathrm{~N} 22-22)\left(\mathrm{H}_{2} \mathrm{O}\right)_{2}(\mathrm{OTf})_{2}\right]^{2+} \mathbf{2}$ and $\left[\mathrm{Cu}_{2}(\text { apyhist })_{2} \mathrm{dpam}\right]^{4+}$ 4, with $[L$-Dopa $]=8.0 \mathrm{mM}$, in phosphate buffer $(50 \mathrm{mM}, \mathrm{pH} 7.0)$, at $25^{\circ} \mathrm{C}$. 
Table 6

Determined values for kinetic constants in the oxidation of $L$-dopa, catalyzed by the copper(II) complexes studied. Reaction at $25^{\circ} \mathrm{C}$, in phosphate buffer $(50 \mathrm{mM}, \mathrm{pH}=7.00)$.

\begin{tabular}{lll}
\hline Copper complex & $\begin{array}{l}\text { Pseudo-first order } \\
\text { kinetic constant, } \\
\mathrm{k}_{\mathrm{obs}}, \mathrm{s}^{-1}\end{array}$ & $\begin{array}{l}\text { Second order kinetic } \\
\text { constant, } \mathrm{k}, 10^{2} \mathrm{M}^{-1} \mathrm{~s}^{-1}\end{array}$ \\
\hline$\left[\mathrm{Cu}(\mathrm{N} 22)\left(\mathrm{H}_{2} \mathrm{O}\right) \mathrm{OTf}\right]^{+} \mathbf{1}$ & 0.68 & 0.85 \\
{$\left[\mathrm{Cu}_{2}(\mathrm{~N} 22-22)\left(\mathrm{H}_{2} \mathrm{O}\right)_{2}(\mathrm{OTf})_{2}\right]^{2+} \mathbf{2}$} & 20.4 & 25.5 \\
{$\left[\mathrm{Cu}(\text { apyhist }) \mathrm{H}_{2} \mathrm{O}\right]^{2+} \mathbf{3}$} & 0.156 & 0.195 \\
{$\left[\mathrm{Cu}_{2}(\text { apyhist })_{2} \mathrm{dpam}\right]^{4+} \mathbf{4}$} & $1.91($ step 1) & 2.38 \\
& $0.235($ step 2) & 0.294 \\
Tyrosinase, from mushroom $^{\mathrm{a}}$ & $(108 \pm 9.1)^{\mathrm{b}}$ & \\
\hline
\end{tabular}

a Ref. [26].

b $\mathrm{k}_{\text {cat }}$.

oxidation rates with increasing concentrations of each complex indicated a pseudo-first order reaction, only at very low concentrations of the mononuclear complexes, as shown in Fig. 4B. For both the dinuclear species $\mathbf{2}$ and $\mathbf{4}$ an induction period was observed (Fig. 4C). Considering also a dependence on the concentration of the substrate, a second-order rate constant was calculated for each of these complexes, displayed at Table 6 . In the case of complex $\mathbf{4}$ two steps were observed, probably due to the equilibrium of this dinuclear species with the analogous mononuclear one, since the estimated constant for a second step catalyzed by complex $\mathbf{4}$ is very close to the corresponding value for the analogous mononuclear complex 3.

\subsection{Nuclease activity}

Since DNA is usually an important target for compounds exhibiting potential antitumor properties, the possible activity of the studied complexes as synthetic nucleases was also monitored. In the absence of an added oxidant or reducing agent, no significant changes in DNA were verified by electrophoresis experiments. However, in the presence of hydrogen peroxide, single and double cleavages leading to form II and

\section{A $[\mathrm{Cu}(\mathrm{N} 22)]^{+}$}

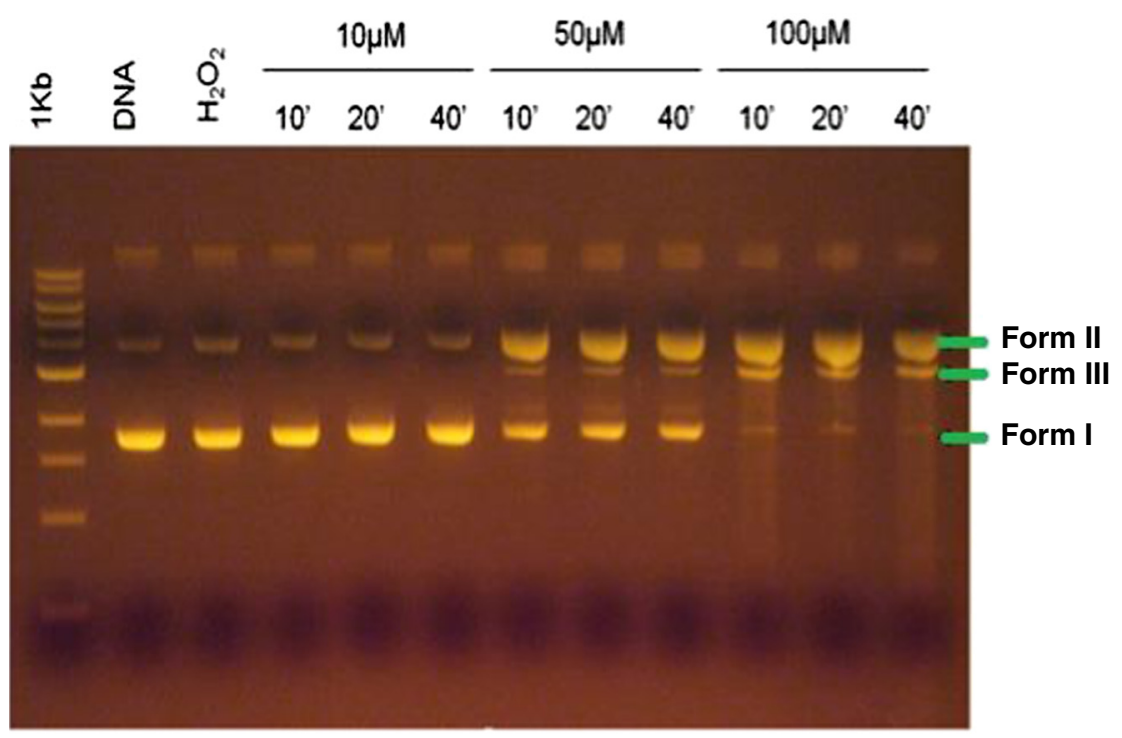

\section{B $\left[\mathrm{Cu}_{2}(\mathrm{~N} 22-22)\right]^{*}$}

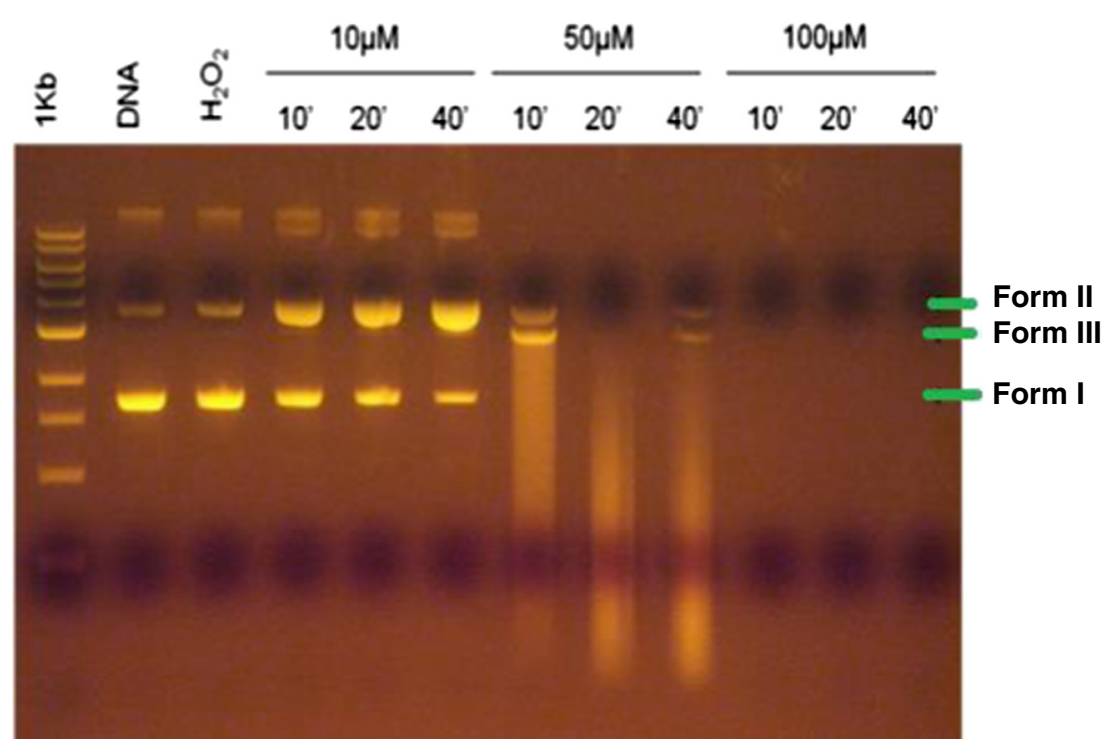

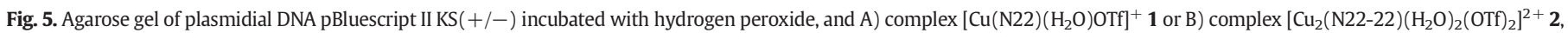
for 10,20 and $40 \mathrm{~min}$, at $37^{\circ} \mathrm{C}$ 
linear DNA form III were observed, in a process dependent on the concentration of the copper species, in the range $10-100 \mu \mathrm{M}$, and almost independent of the incubation time (up to $40 \mathrm{~min}$ ). The reactivity of complexes $\mathbf{1}$ and $\mathbf{2}$ can be compared in Fig. 5. The mononuclear species $[\mathrm{Cu}(\mathrm{N} 22)]^{+} 1$ was not active up to $40 \mathrm{~min}$, at $10 \mu \mathrm{M}$, although it was able to cause single and double cleavages at 50 and $100 \mu \mathrm{M}$ (Fig. 5A). On the other hand, complex $\left[\mathrm{Cu}_{2}(\mathrm{~N} 22-22)\right]^{2+} \mathbf{2}$ showed to be very active, even at low concentration $(10 \mu \mathrm{M})$. At higher concentrations (50 or $100 \mu \mathrm{M}$ ), a complete degradation of the nucleic acid seems to be occurring, as shown by a continuous band at agarose gel, and complete depletion of form I (Fig. 5B).

For complex $[\mathrm{Cu} \text { (apyhist) }]^{2+} \mathbf{3}$, a more significant nuclease activity was observed, in comparison to complex $\mathbf{1}$, dependent on the concentration used, as displayed in Fig. 6A. Finally, complex $\left.\left[\mathrm{Cu}_{2} \text { (apyhist) }\right)_{2} \mathrm{dpam}\right]^{4+}$ 4 showed a remarkable capacity of cleaving DNA, leading to form II and form III, with quite complete depletion of form I, after 20 min incubation, at $50 \mu \mathrm{M}$ concentration (see Fig. 6B). For better comparison of all the complexes, the ratio of obtained DNA (formII)/DNA (Form I) in each case is shown in Fig. 7. These results pointed to a higher activity of dinuclear complexes regarding the corresponding mononuclear ones, for both pairs of compounds tested.

\subsection{Cell viability of melanomas in the presence of the complexes}

Exposure of TM1MNG3 (Fig. 8A) and B16F10 cells (Fig. 8B) to copper complexes for $24 \mathrm{~h}$ led to a dose-dependent cytotoxicity, as determined by MTT assay. Complexes $\mathbf{2}$ and $\mathbf{4}$ presented the highest toxicities in both melanoma cell lineages. $\mathrm{IC}_{50}$ values ( $95 \%$ confidence interval) were estimated by performing a nonlinear fit of normalized response versus log dose with variable slope using GraphPad Prism software, version 6 . For the dinuclear complexes 2 and $\mathbf{4}$ these values were 16.0 and $15.4 \mu \mathrm{M}$ towards B16F10 cells, or 63.5 and $93.3 \mu \mathrm{M}$ for TM1MNG3 cells, respectively. In contrast, complexes $\mathbf{1}$ and $\mathbf{3}$ were much less toxic for both cell lines. For complex 1 an $\mathrm{IC}_{50}(95 \% \mathrm{CI})$ value of $54.5 \mu \mathrm{M}$ was calculated towards B16F10 cells. However, for complex 3 its corresponding $\mathrm{IC}_{50}$ values could not be reliably estimated, being too high (see Fig. 8) for both cell lines, in a concentration range beyond its solubility. A complete

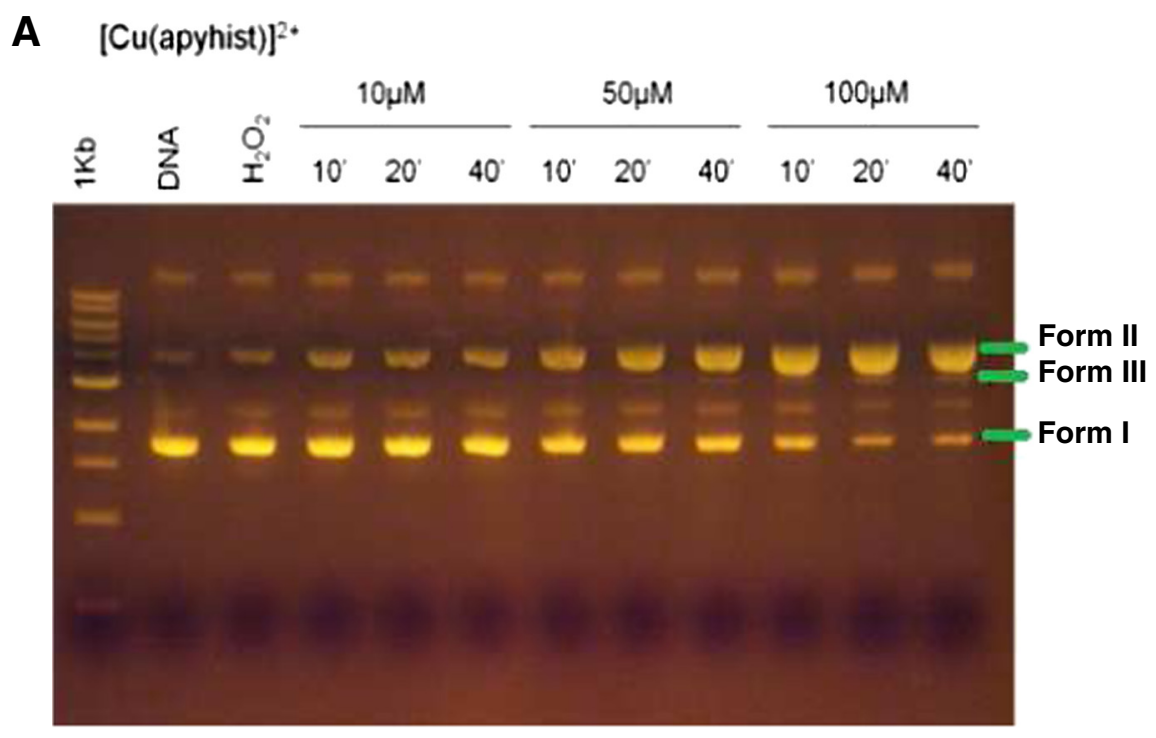

\section{B $\left[\mathrm{Cu}_{2} \text { (apyhist }\right)_{2}$ dpam $]^{4+}$}
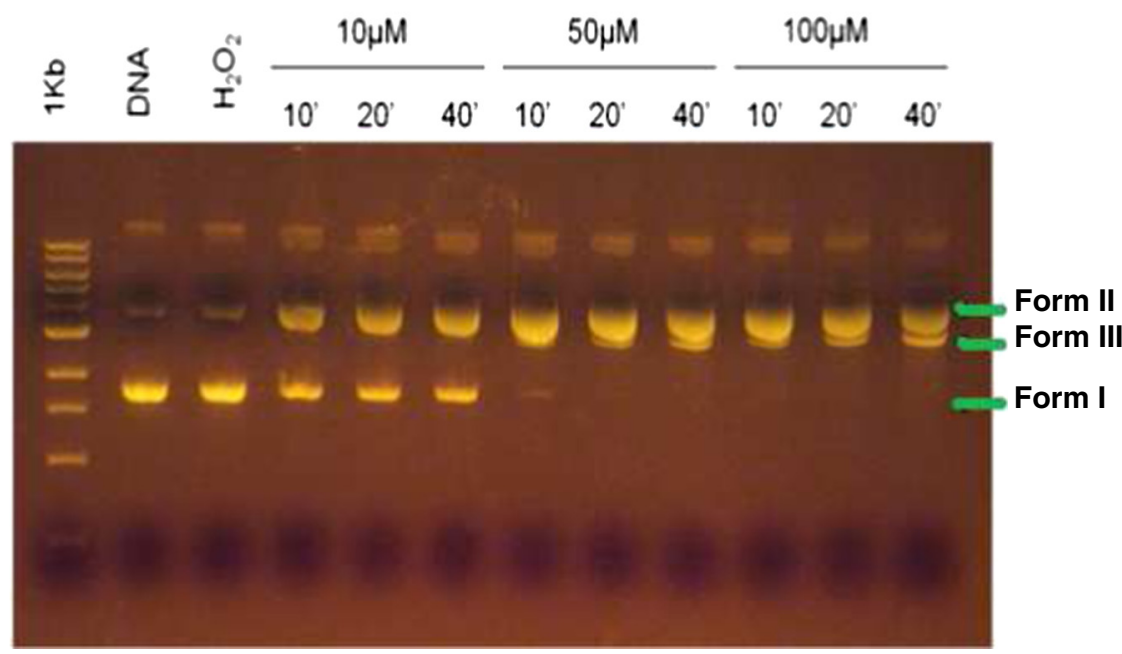

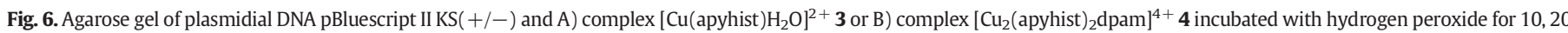
and $40 \mathrm{~min}$, at $37^{\circ} \mathrm{C}$ 

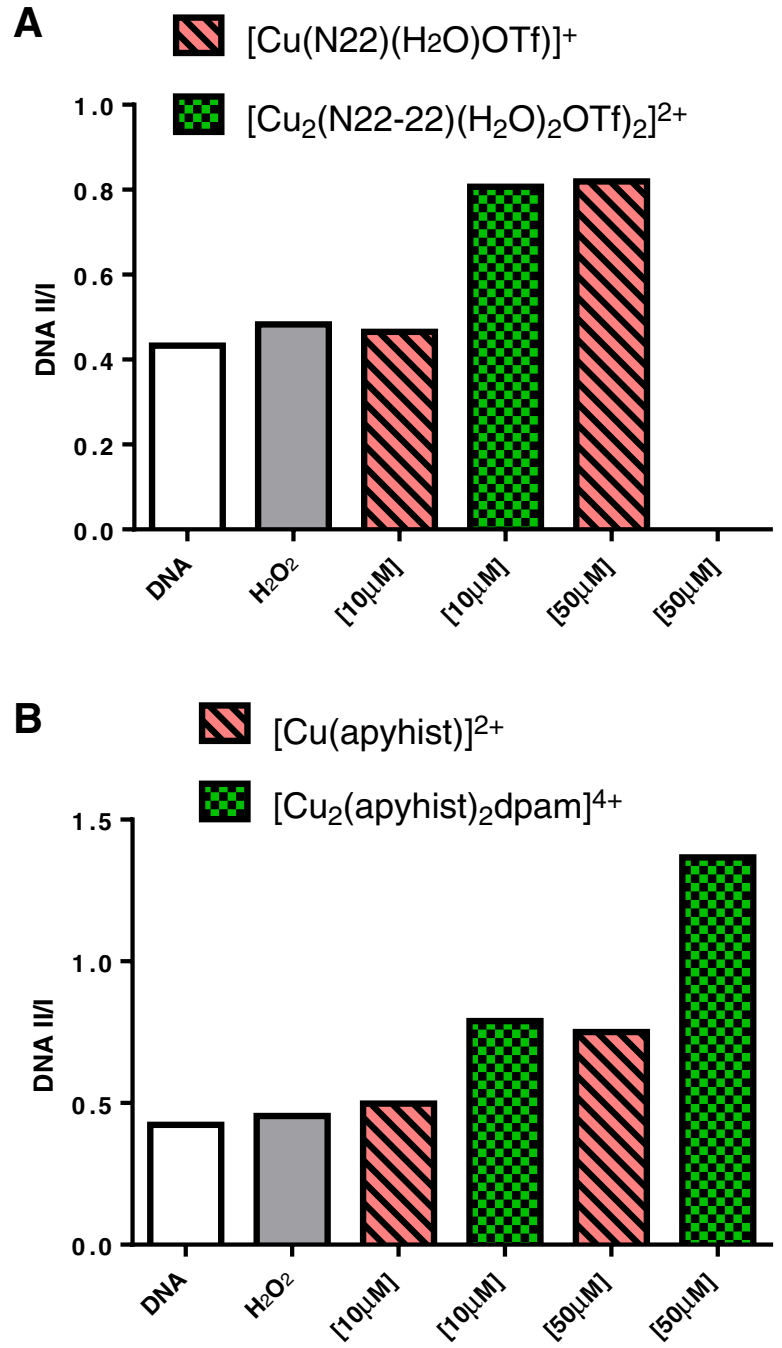

Fig. 7. Corresponding [DNA form II]/[DNA form I] ratio, quantified by using program Image] 1.46, for all the copper complexes studied: A) complexes $\mathbf{1}$ and $\mathbf{2}$; B) complexes $\mathbf{3}$ and $\mathbf{4}$. Lanes: control, plasmidial DNA (36 ng/ $\mu \mathrm{L})$; DNA $+\mathrm{H}_{2} \mathrm{O}_{2}(125 \mu \mathrm{M})$; concentrations of $[\mathrm{CuL}]$, as indicated.

table with the corresponding calculated values is available at Supplementary Information.

These findings indicate that the dinuclear complexes present a more intense cytotoxic effect than their corresponding mononuclear complexes. Moreover, the dinuclear species were much more reactive towards B16F10 cells (Fig. 8B) than to TM1MNG3 ones (Fig. 8A), especially at low concentrations $(<50 \mu \mathrm{M})$. These two types of cells differ remarkably on its melanin content. B16F10 cells are heavily melanogenic, while TM1MNG3 cells have no detectable melanin, as verified in our previous work [18]. Therefore, the melanin level in B16F10 cells seems to make them more susceptible to the dinuclear complexes toxicity.

\section{Conclusions}

All the studied copper(II) complexes showed good thermodynamic stability, in comparison to copper ion inserted at HSA, as attested by $\mathrm{CD}$ measurements. Complexes $\mathbf{1}$ and $\mathbf{2}$ exhibited the expected competitive behavior between the polydentate ligand and the selective $\mathrm{N}$-terminal site of the protein in coordinating the metal ion [17]. However, complex 4 displayed a predominant interaction at Cys34 site, already reported to complex 3 [25] containing the same ligand. None of the complexes was able to modify noticeably the $\alpha$-helix percentage of the protein.
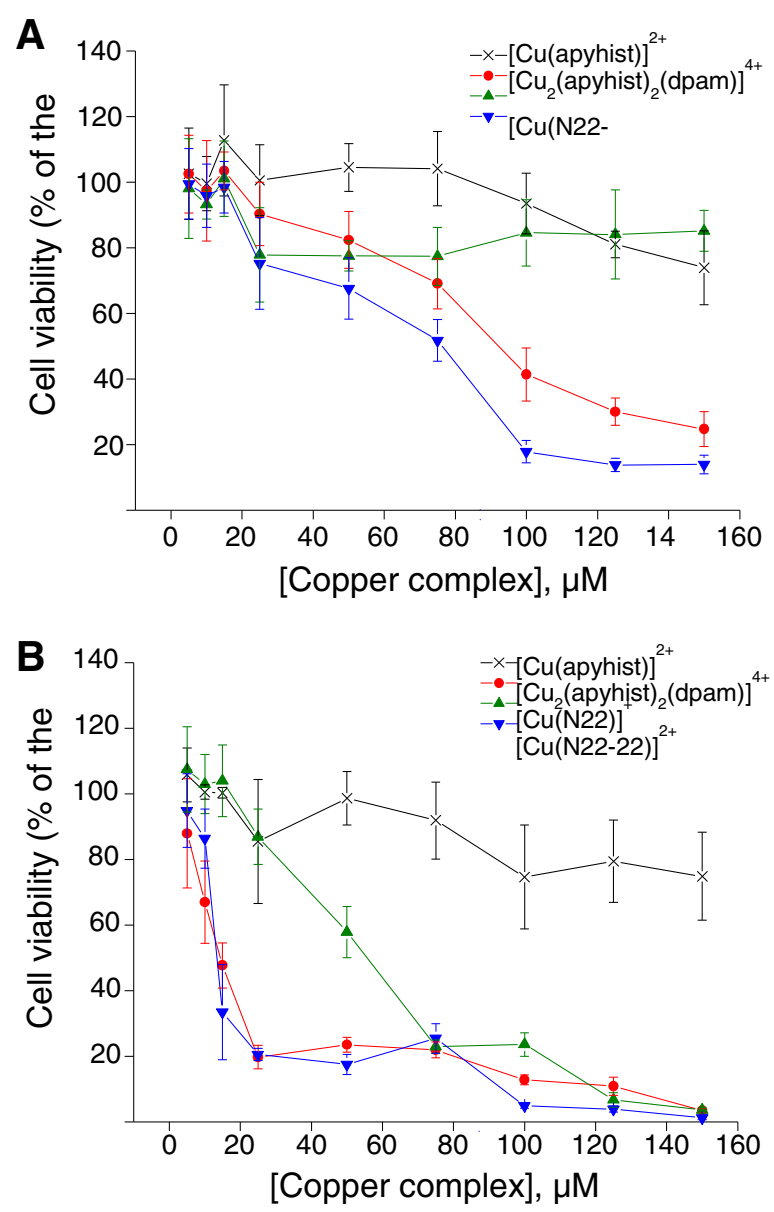

Fig. 8. A) Cellular viability assay of TM1MNG3 melanomas after incubation at $37^{\circ} \mathrm{C}$ for $24 \mathrm{~h}$ with different concentrations of all copper(II) complexes studied; B) Cellular viability assay of B16F10 melanomas after incubation at $37^{\circ} \mathrm{C}$, for $24 \mathrm{~h}$, with different concentrations of all copper(II) complexes studied.

A significant inhibition of melanoma viability was observed for both lineage B16F10 and TM1MNG3 cells incubated with each one of the dinuclear complexes, with $\mathrm{IC}_{50}$ values in the range $20-100 \mu \mathrm{M}$, although complex $\mathbf{2}$ exhibited a much higher tyrosinase activity than complex 4. This complex 4 is probably in equilibrium with the corresponding mononuclear complex $\mathbf{3}$ during the catalytic cycle, since two steps were observed in the catalyzed oxidation of $L$-dopa, with the second step rate constant very close to that verified in the reaction catalyzed by complex 3. The corresponding mononuclear complexes showed to be remarkably less reactive both as inhibitors of melanoma proliferation, and as tyrosinase mimics. Further, the dinuclear species exhibited higher activity as nuclease agents than the corresponding mononuclear compounds, being able of causing single and double DNA strand cleavages, at concentrations of $10-50 \mu \mathrm{M}$, in the presence of hydrogen peroxide. For the corresponding mononuclear species double cleavage was observed only at higher concentrations, in the range $50-100 \mu \mathrm{M}$.

Those results indicated that the dinuclear structure of such copper complexes is decisive for its inhibition of melanoma cells proliferation as well as for their tyrosinase mimicking, and efficient nuclease activity. A possible explanation for the observed higher activity of dinuclear species could be an influence of its structure in the melanogenesis process, simultaneously occurring in melanoma cells. Indeed, heavily melanogenic cells as those of B16F10 lineage were shown to be more susceptible to the dinuclear species than TM1MNG3 cells with negligible content of melanin. Besides DNA, these dinuclear complexes could have another intracellular target. A better elucidation of the mechanism of action of such 
complexes regarding the viability of melanoma cells requires further studies, actually in development in our lab.

\section{Abbreviations}

apyhist imine ligand prepared from 2-(acetyl)pyridine and histamine CD circular dichroism

CT-DNA calf thymus DNA

dpam synthesized bridge-ligand, diphenyl-2,2'-aminomethyl

DPPH $\quad \alpha, \alpha^{\prime}$-diphenyl- $\beta$-picrylhydrazyl

EPR electron paramagnetic resonance

ESI electrospray ionization

FAB fast atomic bombardment

HSA human serum albumin

ICP-OES Inductively Coupled Plasma Optical Emission Spectroscopy

L-dopa L-3,4-dihydroxyphenylalanine

MS mass spectrometry

N22 tridentate amine-imine ligand (as shown in Fig. 1)

N22-22 polydentate dinucleating amine-imine ligand (as shown in Fig. 1)

TAE buffer 40 mM Tris-acetate, 1 mM EDTA buffer solution

TRP-1 tyrosinase related protein 1

TRP-2 tyrosinase related protein 2 (dopachrome tautomerase, EC 5.3.2.3)

\section{Acknowledgments}

Financial support by the Brazilian agencies FAPESP (grants 2011/ 50318-1 and 2014/09367-7), CNPq (grant 302606/2010-6), INCT Redox Processes in Biomedicine-Redoxoma (Programa Institutos Nacionais de Ciência e Tecnologia, CNPq/FAPESP/MCT, Proc. 573530/2008-4), the NAP-Redoxoma (Pro-Reitoria de Pesquisa-USP, Proc. 11.1.9352.1.8), CEPID-Redoxoma (grant 2013/07937-8), and Project CAPESP-USP/ COFECUB (grant 2008.1.818.46.0) is gratefully acknowledged.

\section{Appendix A. Supplementary data}

Supplementary data to this article can be found online at http://dx. doi.org/10.1016/j.jinorgbio.2015.05.007.

\section{References}

[1] A. Sanchez-Ferrer, J.N. Rodriguez-Lopez, F. Garcia-Canovas, F. Garcia-Carmona, Biochim. Biophys. Acta 1247 (1995) 1-11.

[2] R. Halaban, S.H. Pomerantz, S. Marshall, D.T. Lambert, A.B. Lerner, J. Cell Biol. 97 (1983) 480-488.

[3] J.D. Simon, D. Peles, K. Wakamatsu, S. Ito, Pigment Cell Melanoma Res. 22 (2009) 563-579.

[4] A.A. Suzukawa, A. Vieira, S.M.B. Winnischofer, A.C. Scalfo, P. Di Mascio, A.M. da Costa Ferreira, J.-L. Ravanat, D. de L. Martins, M.E.M. Rocha, G.R. Martinez, Free Radic. Biol. Med. 52 (2012) 1945-1953.

[5] J. Pawelek, R. Halaban, G. Christie, Nature 258 (1975) 539-540.

[6] R. Halaban, A.B. Lerner, Exp. Cell Res. 108 (1977) 119-125.

[7] L. Benmenni, E.H. Alilou, M. Giorgi, M. Pierrot, M. Réglier, J. Chem. Crystallogr. 24 (1994) 345-552.

[8] G.K. Wang, Q.L. Mi, L.Y. Zhao, J.J. Hu, L.E. Guo, X.J. Zou, B. Liu2, X.G. Xie, J.F. Zhang Q.H. Zhao, Y. Zhou, Chem. Asian. J. 9 (2014) 744-748.

[9] I. Sanyal, M. Mahroof-Tahir, M. Sarwar Nasir, P. Ghosh, B.I. Cohen, Y. Gultneh, R.W. Cruse, A. Farooq, K.D. Karlin, Inorg. Chem. 31 (1992) 4322-4332.

[10] M.J. Scott, R.H. Holm, J. Am. Chem. Soc. 116 (1994) 11357-11367.

[11] E. Peyroux, (Ph. D. thesis) Université Paul Cézanne Aix-Marseille III, 2008.

[12] E. Peyroux, W. Ghattas, R. Hardré, M. Giorgi, B. Faure, A.J. Simaan, C. Belle, M. Réglier, Inorg. Chem. 48 (2009) 10874-10876.

[13] P.A. Vigato, S. Tamburini, Coord. Chem. Rev. 248 (2004) 1717-2128.

[14] W.A. Alves, M.A.A. Azzellini, R.E. Bruns, A.M. Da Costa Ferreira, In. J. Chem. Kinet. 33 (2001) 472-479.

[15] M.A. de A. Azzellini, I.A. Bagatin, A.M. Da Costa Ferreira, Redox Rep. 11 (2006) 25-37.

[16] M.A. de A. Azzellini, M.P. Abbott, A. Machado, M.T.M. Miranda, L.C. Garcia, G.F. Caramori, M.B. Gonçalves, H.M. Petrilli, A.M. Da Costa Ferreira, J. Braz. Chem. Soc. 21 (2010) 1303-1317.

[17] M. Rozga, M. Sokolowska, A.M. Protas, W. Bal, J. Biol. Inorg. Chem. 12 (2007) 913-918.

[18] B.E. Borges, V.R. Teixeira, H. Marcia, C. Appel, A. Steclan, F. Rigo, F. Filipak Neto, A.M. da Costa Ferreira, R. Chammas, S.M. Zanata, L.S. Nakao, Chem. Biol. Interact. 206 (2013) 37-46.

[19] A.W. Addison, T.N. Rao, J. Reedjijk, J. Van Rijn, G.C. Verschoor, J. Chem. Soc. Dalton Trans. (1984) 1349-1356

[20] U. Sakaguchi, A.W. Addison, J. Chem. Soc. Dalton Trans. (2001) 600-608.

[21] M. Valko, H. Morris, M. Mazur, J. Telser, E.J.L. McInnes, F.E. Mabbs, J. Phys. Chem. B 103 (1999) 5591

[22] M. Sokolowska, K. Pawlas, W. Bal, Bioinorg. Chem. Appl. (2010) 1-7, http://dx.doi. org/10.1155/2010/725153 (article ID 725153).

[23] W. Bal, J. Christodoulou, P.J. Sadler, A. Tucker, J. Inorg. Biochem. 70 (1998) 33-39.

[24] W. Bal, M. Sokołowska, E. Kurowska, P. Faller, Biochim. Biophys. Acta 1830 (2013) 5444-5455.

[25] V.C. Silveira, M.P. Abbott, M. Cavicchioli, M.B. Gonçalves, H.M. Petrilli, L. de Rezende A.T. Amaral, D.E.P. Fonseca, G.F. Caramori, A.M. da Costa Ferreira, Dalton Trans. 42 (2013) 6386-6396

[26] J.N. Rodriguez-Lopez, L.G. Fenoll, P.A. Garcia-Ruiz, R. Varon, J. Tudela, R.N.F. Thorneley, F. Garcia-Canovas, Biochemistry 39 (2000) 10497-10506. 